NBER WORKING PAPER SERIES

\title{
THE EFFECT OF COLLECTIVE \\ BARGAINING LEGISLATION ON \\ STRIKES AND WAGES
}

\author{
Peter C. Cramton \\ Morley Gunderson \\ Joseph S. Tracy
}

Working Paper No. 5105

\section{NATIONAL BUREAU OF ECONOMIC RESEARCH \\ 1050 Massachusetts Avenue \\ Cambridge, MA 02138 \\ May 1995}

We have benefitted from comments by seminar participants at Johns Hopkins University, Stanford University, the University of Maryland, the University of Montreal, and the University of Wisconsin. Financial support is gratefully acknowledged from the National Science Foundation for Cramton and Tracy and a Social Sciences and Humanities Grant for Gunderson. Most of this work was completed while Cramton was a National Fellow at the Hoover Institution, Stanford University, and Gunderson was visiting the National Bureau of Economic Research, Stanford, California. This paper is part of NBER's research program in Labor Studies. Any opinions expressed are those of the authors and not those of the National Bureau of Economic Research.

(C) 1995 by Peter C. Cramton, Morley Gunderson and Joseph S. Tracy. All rights reserved. Short sections of ext, not to exceed two paragraphs, may be quoted without explicit permission provided that full credit, including $(\odot)$ notice, is given to the source. 
NBER Working Paper \#5105

May 1995

\title{
THE EFFECT OF COLLECTIVE \\ BARGAINING LEGISLATION ON \\ STRIKES AND WAGES
}

\begin{abstract}
Using Canadian data on large, private-sector contract negotiations from January 1967 to March 1993, we find that wages and strikes are substantially influenced by labor policy. In particular, we find that prohibiting the use of replacement workers during strikes is associated with significantly higher wages, and more frequent and longer strikes. This is consistent with private information theories of bargaining. We estimate the welfare consequences of a ban on replacement workers, as well as other labor policies. Despite the higher dispute costs, union workers are better off with a ban on replacement workers. The higher wage more than compensates for the more frequent and longer strikes.
\end{abstract}

Peter C. Cramton

Department of Economics University of Maryland

College Park, MD 20742-7211
Morley Gunderson

Department of Economics University of Toronto 150 St. George Street Toronto, Ontario M5S 1A1 CANADA

Joseph S. Tracy

Department of Economics

Columbia University

International Affairs Building

420 West 118th Street

New York, NY 10027

and NBER 


\section{Introduction}

In this paper, we investigate the impact collective bargaining legislation has on wage outcomes and strike incidence and duration. The legislation defines the rules under which firms and unions negotiate labor contracts. Strategic bargaining theories predict how changes in the rules should effect bargaining outcomes. Hence, an empirical study of the impact of the legislation enables the testing of such bargaining theories.

From a policy perspective, it is important to assess whether legislation has the intended effects on bargaining outcomes. Often, collective bargaining legislation is introduced to improve the efficiency of negotiations, for example by reducing the incidence and duration of strikes. We will evaluate to what extent the policies are effective at reducing strike activity. Variations in the rules of bargaining are also likely to influence the balance of power between the union and the firm, and hence affect wages. Indeed, the primary motivation of advocates of a particular legislative initiative may be to shift the balance of power in their favor, even when their stated intentions are to improve efficiency. For this reason, we analyze the wage effects and potential welfare consequences of the various labor policies.

We utilize a data set that includes all private-sector contract negotiations in Canada involving 500 or more workers from January 1967 to March 1993. Canada differs from the U.S. in two important respects, making the Canadian data especially desirable for a study of this sort. First, its labor law is determined mainly at the provincial level, rather than the national level. Hence, there is substantial variation in labor policy both among the provinces and over time. In contrast, the major U.S. labor laws are determined at the national level and have not undergone substantial change since the 1930s. A second difference is that the Canadian data are systematically collected through mandatory reporting requirements; whereas, the U.S. data are collected mostly from voluntary reporting and newspaper accounts. As a result, the Canadian data should be more accurate.

This paper builds on the studies of Gunderson, Kervin, and Reid $(1986,1989)$ and Gunderson and Melino (1990), which first analyzed the effects of labor legislation on strike activity in Canada. We extend their work in a number of ways. First, we look at wages as well as strike incidence and duration, all within the same data set. This allows us to analyze both efficiency and distributional aspects of the policies in a consistent way. Second, we analyze a much longer time horizon, which offers larger sample sizes and greater policy variation. Third, we interpret the results in terms of recent theoretical models of strike activity, and use the results to partially test such theories.

We find that wages and strike incidence and duration are substantially effected by labor policy. The wage effects tend to be strongest and the duration effects tend to be the weakest. 
Policies that make the strike threat more attractive for the union tend to increase wages and strike incidence. For example, a ban on the use of replacement workers leads to significantly higher wages and more frequent strikes. This is consistent with a bargaining model in which the union has multiple ways of putting pressure on the firm. A ban on replacements makes the strike threat more attractive to the union, leading to more strikes and higher wages.

The next section describes our data more fully. Then in section 3 , we present our theoretical perspective. Section 4 discusses the impact of labor policy on wages. Section 5 analyzes the effect of labor policy on strike activity, both incidence and duration. In section 6 , we summarize our results and provide illustrative estimates of the impact of labor policy on welfare.

\section{The Data}

Our Canadian data comes from two main databases, both made available from Labour Canada. The first is the Major Wage Settlements database, which includes wage and other settlement information for all settlements with at least 500 workers. We extracted settlement information for all private sector contracts settled between January 1967 and March 1993. Unfortunately, this database does not include information about strike duration. To get this information, we merged duration and other dispute information from the Work Stoppage database. A detailed description of the data and our variable definitions is provided in the appendix.

Table 1 presents summary statistics about contracts, disputes, and wages for the combined data sets for both the public and private sectors. Despite efforts to reduce strike activity through conciliation and mediation programs, private-sector strikes are both more frequent and longer in Canada than in the U.S. over the same period. (U.S. strike incidence was $10 \%$ with a mean duration of 45 days from 1970 to 1989 , compared with the Canadian strike incidence of $16 \%$ and mean duration of 59 days.) We exclude public sector and construction contract negotiations from our sample, since they are negotiated under substantially different labor law. For example, public sector contracts are often negotiated without a right to strike and many large strikes are ended by legislative action. As a result, strike activity is less in the public sector. Currie and McConnell (1991) analyze the impact of regulations governing the right to strike on public sector wages and strike activity in Canada.

Our policy variables for 1967 to 1986 were taken from Gunderson, Kervin, and Reid (1988). We then extended their variables to the present day from Labour Canada, Industrial Relations Legislation in Canada and CCH Canadian Ltd., Canadian Labour Law Reporter, as well as other sources. In total, there are nine labor policy variables that vary by province and over time for our 27 year sample period. Table 2 presents the labor relations policy variables 
TABLE 1 - SUMmary Statistics of CONTRACTS, DisPuTES, AND Wages

\begin{tabular}{rcccc}
\hline & \multicolumn{2}{c}{500 or more workers } & \multicolumn{2}{c}{ all contracts } \\
\cline { 2 - 5 } Statistic & Private & Public & Private & Public \\
Number of contracts & 5,819 & Sector & Sector & Sector \\
\hline Conciliation incidence (percent) & 31 & 6,798 & $96,692^{a}$ & $41,127^{a}$ \\
Mediation incidence (percent) & 10 & 11 & & \\
Arbitration incidence (percent) & 1 & 10 & & \\
Strike incidence (percent) & 16 & $8^{c}$ & & \\
Mean strike duration (days) & 59 & $35^{c}$ & 49 & \\
Mean dispute duration (days) & 108 & 202 & & \\
Mean person-days lost in strike (000s) & 76 & $44^{c}$ & 8 & \\
Mean real wage (1986 Canadian dollars) & 11.31 & 11.52 & & \\
\hline
\end{tabular}

Notes: Includes negotiations settled from 1967 to March 1993.

${ }^{a}$ Estimated assuming strike incidence is the same as when the contract covers 500 or more workers.

${ }^{b}$ Includes strikes that preceded an arbitrated or legislated settlement.

${ }^{c}$ From Currie and McConnell (1991) for the period 1964-1987. 
for the federal jurisdiction and each of the ten Canadian provinces (Yukon and Northwest Territories are excluded because there are only a few contracts in these regions).

In addition, our data includes numerous contract-specific and region-specific economic variables. Throughout, we control for region, season, union, and industry effects, as well as cubic time trends. We include bargaining-pair fixed effects in some specifications.

\section{Theoretical Perspective}

Our theoretical model of wage bargaining is taken from Cramton and Tracy (1992, 1994a). (See Kennan and Wilson $(1989,1993)$ for surveys of bargaining theory and its relation to strike data.) The union and firm are negotiating over the wage to paid over the life of the contract. The firm has private information about its willingness to pay. Offers are exchanged until a settlement is reached. Prior to settlement, the parties receive their threat payoffs. In the simplest model, the union decides between two possible threats - the union can strike or it can apply pressure on the firm while continuing to work under the terms of the expired contract, which we call holdout.

The central determinant of wages in this model is the size of the "pie," as determined from the value added by a cooperative workforce and the parties' relative threat payoffs. Collective bargaining is a process that indirectly links the union wages to the size of this pie. Strikes and holdouts occur because of the union's uncertainty about the firm's willingness to pay. The firm has an incentive to claim that times are tough even when they are not. Hence, the firm's statements must be backed up with actions to convince the union to accept. The firm's willingness to endure a costly strike or holdout is one means of convincing the union to accept a lower wage.

Policies that reduce the size of the pie should reduce wages. Policies that increase the attractiveness of the strike threat to the union should increase wages.

\subsection{The Basic Model of Wage Bargaining}

A union and a firm are bargaining over the wage to be paid during a contract of duration $T$. The union's reservation wage is common knowledge. Let $v$ be the firm's value of the current labor force working under a contract of duration $T$. The value $v$ is known only to the firm, but it is common knowledge that $v$ is drawn from the distribution $F$ with positive density on the interval $[\ell, h]$.

Bargaining begins with the union selecting a threat $\theta \in\{H, S\}$, either holdout or strike, which applies until a settlement is reached. In the threat $\theta$, the payoff to the union is $x_{\theta}$ and the payoff to the firm is $y_{\theta}(v)=a_{\theta} v-b_{\theta}$, where $a_{\theta} \in[0,1)$ and $b_{\theta} \geq 0$. The term $1-a_{\theta}$, which we call the dispute cost, measures how far the parties are from the Pareto frontier 
TABLE 2 - Labor Relations Policy VARIABLES, 1967 TO 1993

\begin{tabular}{|c|c|c|c|c|c|c|c|c|c|c|c|}
\hline \multirow[b]{2}{*}{ Policy Variable } & \multirow[b]{2}{*}{ Federal } & \multicolumn{10}{|c|}{ Province } \\
\hline & & $\begin{array}{l}\text { British } \\
\text { Columbia }\end{array}$ & Alberta & $\begin{array}{l}\text { Saskatch- } \\
\text { ewan }\end{array}$ & Manitoba & Ontario & Quebec & $\begin{array}{c}\text { New } \\
\text { Bruns- } \\
\text { wick }\end{array}$ & $\begin{array}{l}\text { Nova } \\
\text { Scotia }\end{array}$ & $\begin{array}{l}\text { Prince } \\
\text { Edward } \\
\text { Island }\end{array}$ & $\begin{array}{l}\text { Newfound } \\
\text { land }\end{array}$ \\
\hline $\begin{array}{l}\text { Conciliation officer } \\
\text { only }\end{array}$ & $\begin{array}{c}72: 7 \text { to } \\
93\end{array}$ & $\begin{array}{l}67 \text { to } \\
68: 3\end{array}$ & $\begin{array}{l}68 \text { to } \\
81: 2\end{array}$ & - & $\begin{array}{l}67 \text { to } \\
72: 10\end{array}$ & 67 to 86 & $\begin{array}{l}67 \text { to } \\
77: 11\end{array}$ & $72: 4$ to 93 & 67 to 93 & 67 to 93 & - \\
\hline $\begin{array}{l}\text { Conciliation officer } \\
\text { and board }\end{array}$ & $\begin{array}{l}67 \text { to } \\
72: 6\end{array}$ & - & 67 & - & - & - & - & 67 to $72: 3$ & - & - & 67 to 93 \\
\hline $\begin{array}{l}\text { Cooling-off period } \\
\text { (days) }\end{array}$ & $\begin{array}{c}67 \text { to } 93 \\
\text { (7) }\end{array}$ & $\begin{array}{c}67 \text { to } \\
68: 3(2) \\
68: 4 \text { to } \\
93(3)\end{array}$ & $\begin{array}{c}67 \text { to } \\
81: 2(14) \\
81: 3 \text { to } \\
93(3)\end{array}$ & $\begin{array}{l}83: 7 \text { to } \\
93(2)\end{array}$ & $\begin{array}{c}67 \text { to } \\
72: 10(7)\end{array}$ & $\begin{array}{l}67 \text { to } 93 \\
\text { (14) }\end{array}$ & - & $\begin{array}{l}67 \text { to } 93 \\
\text { (7) }\end{array}$ & $\begin{array}{c}67 \text { to } \\
72: 9(21) \\
72: 10 \text { to } \\
93(14)\end{array}$ & $\begin{array}{c}67 \text { to } \\
75: 4(21) \\
75: 5 \text { to } \\
93(14)\end{array}$ & $\begin{array}{l}67 \text { to } 93 \\
(7)\end{array}$ \\
\hline $\begin{array}{c}\text { Mandatory strike } \\
\text { vote }\end{array}$ & - & 67 to 93 & 67 to 93 & 67 to 93 & $\begin{array}{l}85: 1 \text { to } \\
93\end{array}$ & - & $\begin{array}{c}77: 12 \text { to } \\
93\end{array}$ & $72: 4$ to 93 & 67 to 93 & 67 to 93 & - \\
\hline $\begin{array}{l}\text { Employer initiated } \\
\text { vote option }\end{array}$ & - & - & - & $\begin{array}{l}69: 4 \text { to } \\
72: 4\end{array}$ & - & $\begin{array}{c}80: 6 \text { to } \\
93\end{array}$ & - & - & - & - & - \\
\hline Dues checkoff & $\begin{array}{c}84: 7 \text { to } \\
93\end{array}$ & $\begin{array}{c}77: 9 \text { to } \\
93\end{array}$ & - & $\begin{array}{c}72: 5 \text { to } \\
93\end{array}$ & $\begin{array}{c}72: 11 \text { to } \\
93\end{array}$ & $\begin{array}{c}80: 6 \text { to } \\
93\end{array}$ & $\begin{array}{c}77: 12 \text { to } \\
93\end{array}$ & - & - & - & - \\
\hline $\begin{array}{l}\text { Prohibit replacement } \\
\text { workers }\end{array}$ & - & $\begin{array}{l}93: 1 \text { to } \\
93\end{array}$ & - & - & - & $\begin{array}{l}93: 1 \text { to } \\
93\end{array}$ & $\begin{array}{c}77: 12 \text { to } \\
93\end{array}$ & - & - & - & - \\
\hline Negotiated reopeners & 67 to 93 & - & - & 67 to 93 & 67 to 93 & - & 67 to 93 & 67 to 93 & 67 to 93 & 67 to 93 & 67 to 93 \\
\hline $\begin{array}{l}\text { Reopeners for tech- } \\
\text { nological change }\end{array}$ & 72 to 93 & $\begin{array}{c}73: 11 \text { to } \\
93\end{array}$ & - & $\begin{array}{c}72: 5 \text { to } \\
93\end{array}$ & $\begin{array}{c}72: 11 \text { to } \\
93\end{array}$ & - & - & 89 to 93 & - & - & - \\
\hline
\end{tabular}

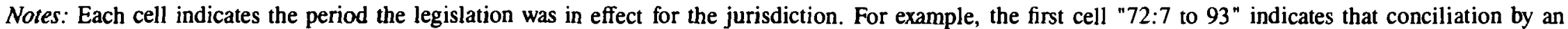
officer only was required in the federal jurisdiction from July 1972 through all of 1993. 
during the threat $\theta$. We define $c_{\theta}=\left(b_{\theta}-x_{\theta}\right) /\left(1-a_{\theta}\right)$ to be the relative payment difference during the threat $\theta$. Since the total payoff in agreement is $v$ and the total payoff in the threat is $a_{\theta} v-b_{\theta}+x_{\theta}$, the pie that the parties are bargaining over is $\left(1-a_{\theta}\right) v+b_{\theta}-x_{\theta}$ $=\left(1-a_{\theta}\right)\left(v+c_{\theta}\right)$. We assume that this pie is positive for all $v \in[\ell, h]$, which implies $c_{\theta}>-\ell$.

Let $w_{0}$ be the current wage under the expired contract. The workers are paid the current wage $w_{0}$ during a holdout, so $b_{H}=x_{H}=w_{0}$ and $c_{H}=0$. We assume there is some inefficiency associated with a holdout: $a_{H}<1$. This inefficiency comes from the workers withholding cooperation in production (a slow down or work-to-rule or other "in plant" strategy).

An outcome of the bargaining, denoted $\langle t, w, \theta\rangle$, specifies the time of agreement $t \in[0$, $T]$, the contract wage $w$ at the time of agreement, and the threat $\theta \in\{H, S\}$ before agreement. For the moment, assume that the union and firm are risk neutral and that the payoff flows, both during the threat and after agreement, are constant over time. The overall payoffs, then, are calculated as a combination of the threat payoff and the agreement payoff, weighted by the fraction of time spent in each outcome, as shown in Figure 1.

Define

$$
D(t)=\frac{1-e^{-r t}}{1-e^{-r T}}
$$

to be the discounted fraction of time spent in dispute if agreement occurs at time $t$, where $r$ is the discount rate. Then given the outcome $\langle t, w, \theta\rangle$, the union's payoff is

$$
U(t, w, \theta)=x_{\theta} D(t)+w(1-D(t)),
$$

and the firm's payoff is

$$
V(t, w, \theta)=y_{\theta}(v) D(t)+(v-w)(1-D(t))
$$

Following the union's threat choice, the union and firm alternate wage offers, with the union making the initial offer. After an offer is made, the other side has two possible responses: (1) a counteroffer, in which case the bargaining continues, or (2) acceptance, in which case the bargaining ends with labor supplied at the offered wage for the remainder of the contracting period $T$. As in Admati and Perry (1987), a bargainer can delay responding to an offer. This assumption leads to the signaling equilibrium in which the firm signals its value through its willingness to delay agreement. For simplicity, we assume that the minimum time between offers is arbitrarily small.

The equilibrium takes a simple form. If $w_{0}$ is sufficiently low (below an indifference level $\tilde{w})$ the union decides to strike; otherwise $\left(w_{0} \geq \tilde{w}\right)$ the union decides to hold out. The 
Figure 1 - Payoffs from Bargaining Outcome $\langle t, w, \theta\rangle$

Payoffs During Threat $\theta$

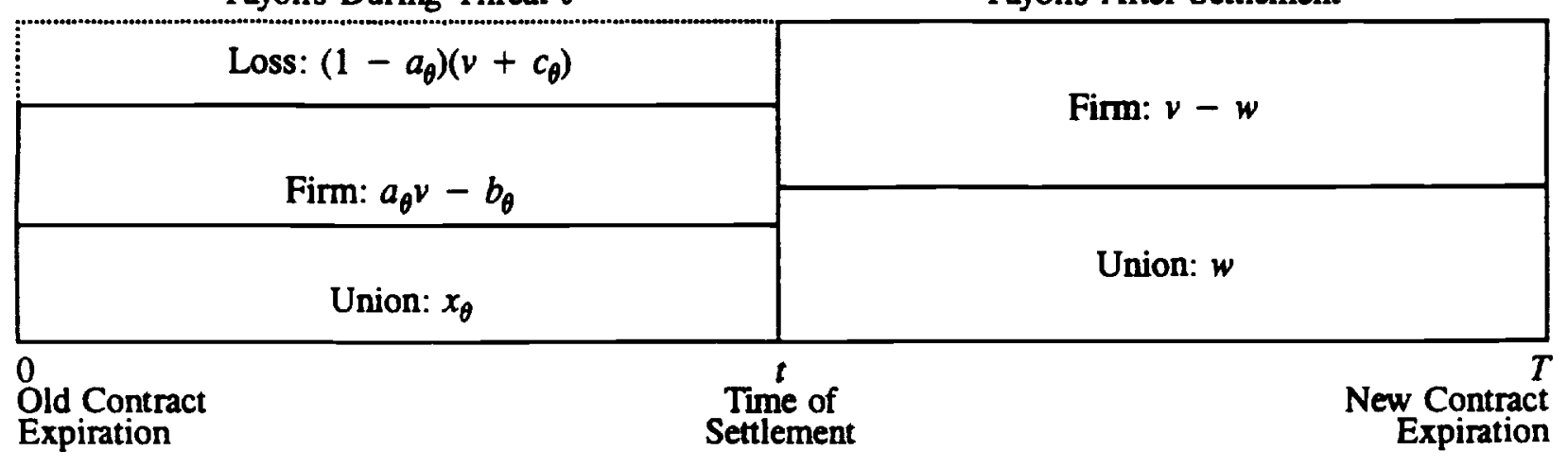

Payoffs After Settlement

Expiration 
indifference level $\tilde{w}$ depends on $r, T, F$, and the threat payoffs $\left(x_{\theta}, y_{\theta}\right)$ for $\theta=\{H, S\}$. A second indifference level $m \in(\ell, h)$ is determined by the union's initial offer. The firm accepts the union's initial offer if its valuation is above $m$ and otherwise rejects the offer.

The signaling equilibrium is characterized in the following three propositions from Cramton and Tracy (1992). First we look at the subgame after a threat $\theta \in\{H, S\}$ is chosen.

Proposition 1. Let $\theta=\left(x_{\theta}, y_{\theta}\right)$ be the threat chosen by the union. In the limit as the time between offers goes to zero, there is a perfect Bayesian equilibrium with the following form:

- The union makes an immediate offer of $w_{\theta}(m)=x_{\theta}+1 / 2\left(1-a_{\theta}\right)\left(m+c_{\theta}\right)$, where $m\left(c_{\theta}\right) \in(\ell, h)$ maximizes

$$
\left(m+c_{\theta}\right)(1-F(m))+\int_{\ell}^{m} \frac{\left(v+c_{\theta}\right)^{2}}{m+c_{\theta}} d F(v) .
$$

- The firm accepts the offer if $v \geq m$. Otherwise, if $v<m$, the firm waits until $(m-v) /\left(m+c_{\theta}\right)$ of the contract period has passed before offering $w_{\theta}(v)=x_{\theta}+1 / 2(1-$ $\left.a_{\theta}\right)\left(v+c_{\theta}\right)$, which is accepted immediately by the union.

- The union's expected payoff from the threat $\theta$ is $U_{\theta}$, the firm's expected payoff is $V_{\theta}$, and the expected loss is $L_{\theta}$, where

$$
\begin{aligned}
& U_{\theta}=x_{\theta}+\left(1-a_{\theta}\right)\left(m+c_{\theta}\right)(1-F(m)) \\
& V_{\theta}=a_{\theta} E(v)-b_{\theta}+\left(1-a_{\theta}\right) \int_{m}^{h}\left(v+c_{\theta}\right) d F(v) \\
& L_{\theta}=\left(1-a_{\theta}\right)\left[c_{\theta}-\left(m+2 c_{\theta}\right)(1-F(m))+\int_{\ell}^{m} v d F(v)\right] .
\end{aligned}
$$

In this model, wages should fall with longer strike durations, as the union becomes more pessimistic about the firm's willingness to pay. This is analogous to the familiar union concession curve of Ashenfelter and Johnson (1969).

For a given threat $\theta$, we can determine how dispute incidence and duration respond to changes in the threat $\theta$ or to changes in the distribution of $v$. The following proposition says that dispute activity increases with uncertainty. Dispute activity also increases when the threat $\theta$ becomes more attractive to the union $\left(c_{\theta}\right.$ falls).

Proposition 2. Suppose that $m\left(c_{\theta}\right)$ uniquely maximizes $(\mathrm{M})$. Dispute incidence $F\left(m\left(c_{\theta}\right)\right)$ and dispute duration $D\left(v, c_{\theta}\right)=\left(m\left(c_{\theta}\right)-v\right) /\left(m\left(c_{\theta}\right)+c_{\theta}\right)$ increase as $c_{\theta}$ decreases. Likewise, dispute incidence and dispute duration increase with a linear, mean-preserving spread of the distribution $F$. 
Dispute activity in this model depends on the amount of uncertainty about private information. This is a robust finding of strategic bargaining models. However, it is a difficult implication to test, since we do not observe the parties' private information. Even finding good proxies for the extent of private information uncertainty is difficult. Interestingly, there is no necessary relationship between dispute activity and the bargaining inefficiency $1-a_{\theta}$. This is in contrast to the joint cost hypothesis (Kennan 1980; Reder and Neumann 1980), which posits that disputes should be less frequent and shorter when they are more costly.

Our third proposition demonstrates that the threat decision critically depends on the current wage.

Proposition 3. If $w_{0}<\tilde{w}$, the union strikes; if $w_{0} \geq \tilde{w}$, the union chooses to hold out, where

$$
\tilde{w}=x_{S}+\left(1-a_{S}\right)\left(m\left(c_{S}\right)+c_{S}\right)\left[1-F\left(m\left(c_{S}\right)\right)\right]-\left(1-a_{H}\right) m(0)[1-F(m(0))]
$$

and $m\left(c_{\theta}\right)$ maximizes $(\mathrm{M})$.

The intuition is that the union strikes if and only if the higher bargaining costs associated with a strike are more than made up for by a higher wage. If the current wage is sufficiently high this is not the case - the holdout threat is preferred.

\subsection{Wage Bargaining with Time-Varying Threat Payoffs}

Some of the model's predictions change when the model is extended to allow for timevarying threat payoffs (Cramton and Tracy 1994b). Threat payoffs change over time as replacement workers are hired and trained, as strikers find temporary jobs, as inventories or strike funds run out, or as public assistance to strikers varies based on the length of the strike. A basic finding of this model is that if dispute costs increase in the long run, then dispute durations are longer and wages decline more slowly during the shortrun (and may even increase). Dispute duration is determined from the firm's incentive compatibility condition. In equilibrium, a firm waits until the marginal benefit of waiting (a lower wage) balances the marginal cost of waiting (additional dispute costs). The increase in long run dispute costs effectively magnifies the potential efficiency gains from settlement. This implies a greater dispersion of wage settlements between the high $v$ firms and the low $v$ firms. Hence, the incentive for signaling a low $v$ increases with the long run dispute cost. However, the dispute cost in the shortrun is constant, so duration must increase to balance the costs and benefits of waiting to signal a low $v$.

This extension suggests that strike durations are longer and wages fall more slowly if strike costs increase over time, say, as inventories and strike funds run out. [Alternatively, wages increase with strike duration if we assume that the primary source of uncertainty is over the union's willingness to accept. Longer disputes reveal to the firm the union's 
unwillingness to settle at a low wage.] Likewise, strike durations are shorter and wages fall more quickly if strike costs decrease over time, say, as replacement workers are hired and trained.

\section{Impact of Labor Policy on Wages}

The game-theoretic models of bargaining make strong predictions about how wages should be effected by changes in the threat payoffs. A robust finding across models is that policies that improve the union's strike payoff and reduce the firm's strike payoff will lead to higher wage settlements. Policies such as a ban on replacement workers provide an excellent opportunity for testing the theory. Most prior studies have focused on how labor policy influences strike activity. Examples include Gunderson, Kervin, and Reid $(1986,1989)$ and Gunderson and Melino (1990). The effect of labor policy on wages, however, is sometimes more direct (at least in the theory) and is therefore a good candidate for testing the theory. This is the case for the ban on replacement workers, which makes the strike threat more attractive for the union; hence, we should expect wages to be significantly higher when replacements are banned. For most of the other policy variables the implication on wages is less clear.

Table 3 gives estimates of the impact of labor policy on the real wage. In columns (1) and (3) the relationship between strike duration and the wage is assumed to be linear. Columns (2) and (4) permit a nonlinear relationship between strike duration and the wage by using six indicators for strike duration. Not surprisingly, the main determinant of the current wage is the previous wage (with the impact interpreted relative to the omitted category of no strike). Hence, by including the real previous wage in the regression, which we do in columns (3) and (4), our estimates are similar to a regression where the dependent variable is the change in the real wage. The first two columns do not control for the real wage in the previous contract. These columns measure how the level of wages is effected by the variables.

With a few exceptions, whether or not the previous real wage is controlled for in the regression, the results are similar in sign and significance. Since our primary focus is on the effect of policy variables on long-run wage levels, we focus our discussion on the results of Columns (1) and (2), and especially on those that are statistically significant.

The variable with the clearest theoretical predictions - the ban on replacement workers - has the strongest wage effect, increasing real wages by 10.6 percent. (When bargainingpair fixed effects are controlled for, the impact of the ban on replacement workers is reduced, but still significant at 3.6 percent. Most of the other results remain the same). 
Clearly, the ban on replacement workers shifts bargaining power to the union, and this is reflected in the magnitude of the wage settlement.

Conciliation has little effect on wages, although the requirement for a conciliation board is associated with higher real wages (marginally significant). Cooling-off periods are associated with lower real wages, possibly because they moderate wage demands of the union and they enable the employer to prepare for a possible strike. The right to re-open the agreement in the event of technological change is associated with higher real wages, presumably reflecting the enhanced bargaining power of the union when such a right is present.

While these policy variables had impacts that were consistent with theoretical expectations, this was not the case with the employer initiated vote option which was associated with higher real wages in spite of the fact that it should increase the bargaining power of employers. We have no adequate explanation for this result. However, the policy is identified almost exclusively from its existence in Ontario since the middle of 1980 . Hence it may be picking up some unobserved effects that increased real wages in that province at that time. The other unexpected relationship is from the compulsory dues check-off which is associated with a lower real wage in spite of the fact that it should increase the bargaining power of the union. This may reflect the possibility that this union security provision, which can be important for the survival of the union, was granted in return for some other quid pro quo that led to lower wages.

The results with respect to the non-policy variables generally seem reasonable. The existence of a COLA clause is associated with higher real wages since they automatically offset at least some of the negative effect of inflation. Longer contracts are associated with higher real wages, possibly as the quid pro quo for the industrial peace and stability of such contracts. Larger bargaining units have higher real wages, reflecting the well-known positive relationship between wages and firm size. Real wages are also higher in contracts where the manufacturing wage in the province is high. Wages are higher when only a small fraction of the bargaining unit goes on strike presumably because that small fraction can disrupt the production process, with the employer still incurring the payroll cost of the non-striking employees. This apparently offsets any tendency for the bargaining power of the union to be reduced if the non-striking portion of the bargaining unit can replace the strikers. The use of conciliation or mediation also leads to higher wage settlements.

The similarity of the coefficients on the strike duration indicators highlight that it is the occurrence of the strike rather than its duration that leads to higher wages. When the strike duration categories of equation (2) are replaced by a single dummy variable reflecting the existence of a strike (equation 1), that variable has a significant coefficient of 0.09 . Longer 
TABLE 3 - Estimates of THE IMPaCt of Labor Policy on the Real Wage

\begin{tabular}{|c|c|c|c|c|}
\hline \multirow[b]{2}{*}{ Variable } & \multicolumn{4}{|c|}{ log Real Wage } \\
\hline & (1) & (2) & (3) & (4) \\
\hline \multicolumn{5}{|l|}{ Policy variables: } \\
\hline Conciliation officer & $\begin{array}{c}-0.000 \\
(0.05)\end{array}$ & $\begin{array}{c}-0.000 \\
(0.03)\end{array}$ & $\begin{array}{l}0.013^{* *} \\
(2.73)\end{array}$ & $\begin{array}{l}0.013^{* *} \\
(2.82)\end{array}$ \\
\hline Conciliation officer and board & $\begin{array}{c}0.030 \\
(1.37)\end{array}$ & $\begin{array}{c}0.030 \\
(1.37)\end{array}$ & $\begin{array}{l}0.018 * * \\
(2.20)\end{array}$ & $\begin{array}{l}0.019^{* *} \\
(2.28)\end{array}$ \\
\hline Cooling-off period (days) & $\begin{array}{c}-0.005^{* *} \\
(3.08)\end{array}$ & $\begin{array}{l}-0.005^{* *} \\
(3.11)\end{array}$ & $\begin{array}{c}-0.003^{* *} \\
(4.95)\end{array}$ & $\begin{array}{c}-0.003^{* *} \\
(4.93)\end{array}$ \\
\hline Mandatory strike vote & $\begin{array}{c}-0.016 \\
(0.96)\end{array}$ & $\begin{array}{c}-0.016 \\
(0.96)\end{array}$ & $\begin{array}{r}0.005 \\
(0.79)\end{array}$ & $\begin{array}{r}0.005 \\
(0.79)\end{array}$ \\
\hline Employer initiated vote option & $\begin{array}{l}0.059 * * \\
(3.78)\end{array}$ & $\begin{array}{l}0.059^{* *} \\
(3.76)\end{array}$ & $\begin{array}{c}0.076^{* *} \\
(12.96)\end{array}$ & $\begin{array}{l}0.076^{* *} \\
(13.01)\end{array}$ \\
\hline Compulsory dues checkoff & $\begin{array}{c}-0.048 * * \\
(3.60)\end{array}$ & $\begin{array}{c}-0.048^{* *} \\
(3.60)\end{array}$ & $\begin{array}{c}-0.031^{* *} \\
(6.12)\end{array}$ & $\begin{array}{c}-0.031^{* *} \\
(6.18)\end{array}$ \\
\hline Prohibit replacement workers & $\begin{array}{l}0.106^{* *} \\
(4.62)\end{array}$ & $\begin{array}{l}0.106 * * \\
(4.63)\end{array}$ & $\begin{array}{l}0.039 * * \\
(4.55)\end{array}$ & $\begin{array}{l}0.040^{* *} \\
(4.60)\end{array}$ \\
\hline Right to reopen negotiations & $\begin{array}{c}0.021 \\
(1.12)\end{array}$ & $\begin{array}{c}0.021 \\
(1.10)\end{array}$ & $\begin{array}{c}-0.006 \\
(0.83)\end{array}$ & $\begin{array}{c}-0.006 \\
(0.79)\end{array}$ \\
\hline Reopen if technological change & $\begin{array}{l}0.031^{* *} \\
(2.04)\end{array}$ & $\begin{array}{l}0.030 * * \\
(2.01)\end{array}$ & $\begin{array}{l}0.014^{* *} \\
(2.53)\end{array}$ & $\begin{array}{l}0.014^{* *} \\
(2.54)\end{array}$ \\
\hline \multicolumn{5}{|l|}{ Other variables: } \\
\hline Anti-inflation board & $\begin{array}{c}-0.010 \\
(1.06)\end{array}$ & $\begin{array}{c}-0.010 \\
(1.06)\end{array}$ & $\begin{array}{l}-0.039 * * \\
(10.48)\end{array}$ & $\begin{array}{l}-0.038^{* *} \\
(10.45)\end{array}$ \\
\hline COLA clause in contract & $\begin{array}{l}0.074^{* *} \\
(10.81)\end{array}$ & $\begin{array}{l}0.073^{* *} \\
(10.77)\end{array}$ & $\begin{array}{c}0.026^{* *} \\
(10.01)\end{array}$ & $\begin{array}{l}0.026^{* *} \\
(9.96)\end{array}$ \\
\hline Contract duration (log days) & $\begin{array}{l}0.025^{* *} \\
(3.16)\end{array}$ & $\begin{array}{l}0.025^{* *} \\
(3.18)\end{array}$ & $\begin{array}{c}0.000 \\
(0.01)\end{array}$ & $\begin{array}{c}0.000 \\
(0.03)\end{array}$ \\
\hline Bargaining unit size (log) & $\begin{array}{l}0.030^{* *} \\
(8.07)\end{array}$ & $\begin{array}{l}0.030 * * \\
(8.08)\end{array}$ & $\begin{array}{r}0.000 \\
(0.59)\end{array}$ & $\begin{array}{c}0.000 \\
(0.56)\end{array}$ \\
\hline Real previous wage (log) & & & $\begin{array}{c}0.915^{* *} \\
(179.07)\end{array}$ & $\begin{array}{c}0.915^{* *} \\
(179.02)\end{array}$ \\
\hline Provincial unemployment rate & $\begin{array}{l}0.153 \\
(0.97)\end{array}$ & $\begin{array}{c}0.143 \\
(0.91)\end{array}$ & $\begin{array}{c}-0.029 \\
(0.49)\end{array}$ & $\begin{array}{c}-0.029 \\
(0.50)\end{array}$ \\
\hline Provincial real manufacturing wage (log) & $\begin{array}{l}0.532 * * \\
(7.25)\end{array}$ & $\begin{array}{l}0.533^{* *} \\
(7.26)\end{array}$ & $\begin{array}{c}-0.053^{*} \\
(1.92)\end{array}$ & $\begin{array}{c}-0.052^{*} \\
(1.88)\end{array}$ \\
\hline
\end{tabular}




\begin{tabular}{|c|c|c|c|c|}
\hline \multirow[b]{2}{*}{ Variable } & \multicolumn{4}{|c|}{ log Real Wage } \\
\hline & (1) & (2) & (3) & (4) \\
\hline Fraction of bargaining unit on strike & $\begin{array}{l}-0.082^{* *} \\
(3.53)\end{array}$ & $\begin{array}{l}-0.081^{* *} \\
(3.46)\end{array}$ & $\begin{array}{l}-0.028^{* *} \\
(3.21)\end{array}$ & $\begin{array}{l}-0.028 * * \\
(3.23)\end{array}$ \\
\hline Conciliation used & $\begin{array}{l}0.012^{*} \\
(1.85)\end{array}$ & $\begin{array}{l}0.012^{*} \\
(1.86)\end{array}$ & $\begin{array}{l}0.004 \\
(1.55)\end{array}$ & $\begin{array}{r}0.004 \\
(1.54)\end{array}$ \\
\hline Mediation used & $\begin{array}{l}0.023^{* *} \\
(2.48)\end{array}$ & $\begin{array}{l}0.023^{* *} \\
(2.49)\end{array}$ & $\begin{array}{r}0.003 \\
(0.88)\end{array}$ & $\begin{array}{r}0.003 \\
(0.87)\end{array}$ \\
\hline Wage is primary issue & $\begin{array}{r}0.011 \\
(0.75)\end{array}$ & $\begin{array}{l}0.008 \\
(0.49)\end{array}$ & $\begin{array}{r}0.002 \\
(0.32)\end{array}$ & $\begin{array}{r}0.002 \\
(0.32)\end{array}$ \\
\hline Lockout & $\begin{array}{c}-0.020 \\
(0.76)\end{array}$ & $\begin{array}{c}-0.020 \\
(0.76)\end{array}$ & $\begin{array}{l}-0.031 * * \\
(3.10)\end{array}$ & $\begin{array}{l}-0.030^{* *} \\
(3.02)\end{array}$ \\
\hline Rotating strike & $\begin{array}{l}0.018 \\
(0.59)\end{array}$ & $\begin{array}{r}0.021 \\
(0.70)\end{array}$ & $\begin{array}{r}-0.011 \\
(0.99)\end{array}$ & $\begin{array}{c}-0.011 \\
(0.97)\end{array}$ \\
\hline Strike occurred & $\begin{array}{l}0.088^{* *} \\
(3.31)\end{array}$ & & $\begin{array}{r}0.011 \\
(1.11)\end{array}$ & \\
\hline Strike duration (log days) & $\begin{array}{c}-0.002 \\
(0.44)\end{array}$ & & $\begin{array}{l}0.008^{* *} \\
(4.00)\end{array}$ & \\
\hline $\begin{array}{l}\text { Indicators for strike duration: } \\
\begin{array}{ll}\text { (a) } 1-7 \text { days } & (14 \%)\end{array}\end{array}$ & & $\begin{array}{l}0.078 * * \\
(3.04)\end{array}$ & & $\begin{array}{l}0.019^{*} \\
(1.95)\end{array}$ \\
\hline (b) 8-28 days $(27 \%)$ & & $\begin{array}{l}0.088^{* *} \\
(3.53)\end{array}$ & & $\begin{array}{l}0.035^{* *} \\
(3.71)\end{array}$ \\
\hline (c) $29-49$ days $(19 \%)$ & & $\begin{array}{l}0.084^{* *} \\
(3.13)\end{array}$ & & $\begin{array}{l}0.034^{* *} \\
(3.37)\end{array}$ \\
\hline (d) 50-98 days $(21 \%)$ & & $\begin{array}{l}0.072^{* *} \\
(2.66)\end{array}$ & & $\begin{array}{l}0.052^{* *} \\
(5.09)\end{array}$ \\
\hline (e) $99-147$ days $(10 \%)$ & & $\begin{array}{l}0.109^{* *} \\
(3.54)\end{array}$ & & $\begin{array}{l}0.053^{* *} \\
(4.62)\end{array}$ \\
\hline (f) $148+$ days $\quad(9 \%)$ & & $\begin{array}{r}0.050 \\
(1.61)\end{array}$ & & $\begin{array}{l}0.042^{* *} \\
(3.61)\end{array}$ \\
\hline $\begin{array}{l}\text { Controls (number of variables): Region (5), } \\
\text { Season (3), Union (5), Time (3), Industry (32) }\end{array}$ & yes & yes & yes & yes \\
\hline Sample size & 5345 & 5345 & 5345 & 5345 \\
\hline F-test for policy variables ${ }^{a}$ & $\begin{array}{l}7.67 \\
{[0.0000]}\end{array}$ & $\begin{array}{l}7.68 \\
{[0.0000]}\end{array}$ & $\begin{array}{l}22.63 \\
{[0.0000]}\end{array}$ & $\begin{array}{l}22.75 \\
{[0.0000]}\end{array}$ \\
\hline$R^{2}$ & 0.590 & 0.590 & 0.942 & 0.942 \\
\hline
\end{tabular}

Notes: t-statistics in parentheses.

${ }^{a}$ F-test for the joint significance of the policy variables. Probability values in brackets.

*Statistically significant at 0.10 level. ${ }^{* *}$ Statistically significant at 0.05 level. 
strikes do not elicit higher wages; in fact, very long strikes (over 148 days) are associated with declining settlement wages. These results are broadly consistent with those of Card (1990) who found no significant relation between wages and strike duration in his sample of Canadian strikes from 1964 to 1985.

These results do not support the standard wage bargaining model in which the union is uncertain about the firms's willingness to pay, and all bargaining units face the same level of uncertainty. In this theory, longer strikes reveal an inability to pay and hence a lower settlement wage. Introducing, heterogeneity among bargaining pairs over the amount of uncertainty can lead to wages increasing with strike duration as a result of selection bias. The union strikes if the expected wage gain more than offsets the expected bargaining cost. When there is more uncertainty, the chance of a long strike is greater, and thus the union must expect a higher wage gain in order to justify selecting the strike threat. For each bargaining pair the wage falls with strike duration, and yet in aggregate the wage can increase with strike duration, since a long strike is associated with more uncertainty and thus larger wage gains.

This divergence can also be explained by a more general model that recognizes that strike payoffs may change with the duration of the strike (Cramton and Tracy 1994b), or by introducing firm uncertainty about the union's willingness to accept.

\section{Impact of Labor Policy on Strike Activity}

Among all developed countries, Canada has one of the highest rates of strike incidence (16\% in the private sector). In addition, the mean strike duration of 59 days for large private sector bargaining units is one of the highest in the world. With these facts, together with the high quality of Canada's contract data, it is not surprising that several researchers have studied the determinants of strike activity using the Canadian data. Examples include Card (1988), Gunderson, Kervin, and Reid (1986, 1989), Gunderson and Melino (1990), and Harrison and Stewart (1989a,b). Canadian studies that analyze the relationship between strike duration and wage outcomes include Card (1990), Lacroix (1986), and Riddell (1980). Studies that look at other aspects of wages and strike activity in Canada include Auld, Christofides, Swidinsky, and Wilton (1981) and Currie and McConnell (1991).

Table 4 presents logit estimates of strike incidence. The table shows the change in strike probability per unit increase in the independent variable evaluated at the mean strike probability of 0.16 . The overall incidence effects of the policy variables are not as precisely measured as the wage effects, but still a number of coefficients are significant.

The strongest effect is the 16 percentage point increase in strike incidence implied by a ban on replacement workers (roughly a doubling of strike incidence). This positive impact on 
strike incidence is particularly important, given that proponents of a ban on strike replacements have argued that the ban would reduce strike activity. A ban on the use of strike replacements has now been legislated in three Canadian provinces: Quebec (since December 1977), and British Columbia and Ontario (since January 1993). The U.S. Congress recently considered much weaker legislation, a ban on permanent replacements. This positive effect on strike incidence follows from the theory for two reasons. First, a ban on replacements makes the strike threat more attractive to the union and so it is more apt to select the strike threat, rather than holding out (Cramton and Tracy 1992). Second, a ban on replacements eliminates the firm's option to replace the workforce. This option otherwise provides an upper bound on the firm's willingness to pay, effectively truncating the distribution of union uncertainty. Hence, banning the use of replacements eliminates this upper bound on the distribution of the firm's willingness to pay, implying greater uncertainty, which in turn implies more frequent and longer strikes (Kennan and Wilson 1989).

Interestingly, legislation requiring conciliation or cooling-off periods has no effect on strike incidence. Although this legislation is introduced with the intent of reducing strike activity, its effect is insignificant. Firms and unions are unable to resolve their conflict simply by requiring conciliation or cooling-off periods. This finding is consistent with the institutional industrial relations view that cooling-off periods simply provide time for disputes to "heat up" rather than "cool off."

Mandatory strike votes by the rank-and-file reduce strike incidence. This follows from the theory, since the mandatory strike vote limits the union leader's ability to call a strike. Compulsory dues checkoff also reduces strike incidence, possibly because this union security provision provides more certainty about the financial position of the union, and hence its ability to withstand a strike. Finally, the right to reopen negotiations reduces strike incidence, likely because this right limits the importance of the current contract negotiation.

Strike incidence increases with contract length. This would follow from a model where uncertainty creeps into the bargaining as time passes. Hence, there will be more uncertainty with longer contracts. Furthermore, in longer contracts, more issues over which to strike will have accumulated once the contract expires.

Strike incidence increases both with a tight labor market (low unemployment) or a real wage drop in the prior contract. Both of these effects are consistent with a threat choice model in which the union decides whether to strike or holdout. As the strike threat becomes more attractive relative to the holdout threat, strike incidence should increase. The strike threat is more attractive when there is low unemployment, since temporary jobs for strikers are easier to find and the threat of replacement is less credible. Similarly, the holdout threat 
Table 4 - Logit Estimates of the Impact of Labor Policy on STrike InCidence

Strike Incidence

Variable

(1)

(2)

Policy variables:

$\begin{array}{ccc}\text { Conciliation officer } & -0.011 & -0.013 \\ & (0.35) & (0.42) \\ \text { Conciliation officer and board } & -0.020 & -0.022 \\ & (0.33) & (0.37) \\ \text { Cooling-off period (days) } & -0.002 & -0.003 \\ & (0.57) & (0.60) \\ \text { Mandatory strike vote } & -0.060 & -0.062 \\ & (1.54) & (1.58) \\ \text { Employer initiated vote option } & 0.063 & 0.047 \\ & (1.49) & (1.13) \\ \text { Compulsory dues checkoff } & -0.077^{* *} & -0.069 * * \\ & (3.03) & (2.56) \\ \text { Prohibit replacement workers } & 0.170^{* *} & 0.159^{* *} \\ & (2.12) & (1.99) \\ \text { Right to reopen negotiations } & -0.070^{*} & -0.072^{*} \\ & (1.70) & (1.74) \\ \text { Reopen if technological change } & 0.097^{* *} & 0.084^{*} \\ & (2.11) & (1.86)\end{array}$

Other variables:

$\begin{array}{rcc}\text { Anti-inflation board } & -0.040^{*} & -0.044^{* *} \\ & (1.84) & (2.04) \\ \text { COLA in prior contract } & -0.012 & -0.007 \\ & (0.76) & (0.46) \\ \text { Contract duration (log days) } & 0.164^{* *} & 0.166^{* *} \\ & (5.95) & (6.00) \\ \text { Bargaining unit size (log) } & 0.035^{* *} & 0.033^{* *} \\ & (3.81) & (3.55) \\ \text { Prior real percentage wage change } & -0.003^{*} & -0.002 \\ & (1.84) & (1.58) \\ \text { Provincial unemployment rate } & -0.164^{* *} & -0.163 * * \\ & (2.32) & (2.16) \\ \text { Percentage change in employment } & 0.000 & 0.000^{*} \\ & (1.32) & (1.65)\end{array}$


TABLE 4 - Continued

\begin{tabular}{|c|c|c|}
\hline \multirow[b]{2}{*}{ Variable } & \multicolumn{2}{|c|}{ Strike Incidence } \\
\hline & (1) & (2) \\
\hline Provincial real manufacturing wage (log) & $\begin{array}{c}-0.139 \\
(1.41)\end{array}$ & $\begin{array}{c}-0.134 \\
(1.27)\end{array}$ \\
\hline Conciliation used in prior contract & $\begin{array}{l}0.090^{* *} \\
(4.91)\end{array}$ & $\begin{array}{l}0.090^{* *} \\
(4.94)\end{array}$ \\
\hline Mediation used in prior contract & $\begin{array}{l}0.099 * * \\
(3.66)\end{array}$ & $\begin{array}{l}0.100^{* *} \\
(3.70)\end{array}$ \\
\hline Strike in prior contract & $\begin{array}{l}0.035^{*} \\
(1.79)\end{array}$ & \\
\hline $\begin{array}{l}\text { Indicators for prior strike duration: } \\
\qquad \begin{array}{l}\text { (a) } 1-7 \text { days } \\
(14 \%)\end{array}\end{array}$ & & $\begin{array}{l}0.160^{* *} \\
(3.78)\end{array}$ \\
\hline (b) 8-28 days $(28 \%)$ & & $\begin{array}{l}0.115^{* *} \\
(3.47)\end{array}$ \\
\hline (c) $29-49$ days $(18 \%)$ & & $\begin{array}{r}0.050 \\
(1.36)\end{array}$ \\
\hline (d) $50-98$ days $(20 \%)$ & & $\begin{array}{l}-0.069 * * \\
(2.26)\end{array}$ \\
\hline (e) $99-147$ days $(10 \%)$ & & $\begin{array}{l}-0.106^{* *} \\
(2.60)\end{array}$ \\
\hline (f) $148+$ days $(10 \%)$ & & $\begin{array}{r}0.023 \\
(0.49)\end{array}$ \\
\hline $\begin{array}{l}\text { Controls (number of variables): Region (5), } \\
\text { Season (3), Union (5), Time (3), Industry (32) }\end{array}$ & yes & yes \\
\hline$\chi^{2}$-test for policy variables ${ }^{a}$ & $\begin{array}{l}14.50 \\
{[0.1057]}\end{array}$ & $\begin{array}{l}11.99 \\
{[0.2138]}\end{array}$ \\
\hline Log likelihood & -1715 & -1695 \\
\hline
\end{tabular}

Notes: Sample size is 4364 . Change in strike probability per unit increase (evaluated at the mean strike probability of 0.16 ). z-statistics in parentheses.

${ }^{a} \chi^{2}$-test for joint significance of policy variables. Probability values in brackets.

*Statistically significant at 0.10 level. ${ }^{* *}$ Statistically significant at 0.05 level. 
is less attractive when the real wage falls as a result of unanticipated inflation, since this reduced wage is the union's threat payoff during holdout. Cramton and Tracy (1994a) find these same results with U.S. data.

Card (1988) shows, using Canadian data, that strikes are more likely if there is a short strike in the prior contract, but less likely after a long strike. Our sample also exhibits this feature. Compared to when there was not a strike in the prior contract negotiation, a strike is more likely following a short strike (less than 28 days) and less likely following a long strike (50 or more days). Similarly, a small dispute in the prior contract, as indicated by the use of conciliation or mediation, increases the chance of a strike in the current contract.

Table 5 presents estimates of the impact of labor policy on strike duration. The first two columns estimate strike duration for the sample of large strikes, involving 500 or more workers; the last two columns estimate strike duration from the complete set of strikes. Unfortunately, the complete sample of strikes did not have contract information; hence, the missing variables. When the sample is restricted to large strikes, the sample size falls from 12,929 to 708 , and none of the policy coefficients are precisely measured. However, with the full sample of strikes, the coefficients are usually comparable in sign with the subsample of large strikes, and several become significant. Our discussion focuses on the larger sample of all strikes, given the more precise estimates. Both mandatory strike votes and the right to reopen negotiations shorten strikes significantly. Strikes are significantly longer when the wage is the primary issue.

Of greatest policy importance, the ban on replacement workers is associated with substantially longer strike durations (a $36 \%$ increase). This increase in strike durations is consistent with the theory. Without a ban on strike replacements, the firm's longrun threat is to replace the workforce. Carrying out this threat would increase the firm's strike costs in the shortrun, but reduce them in the longrun (after the replacements are in place and productive). Cramton and Tracy (1994b) show that a decline in firm strike costs over the course of the strike implies shorter strike durations. Hence, a ban on replacements, which would prevent the firm from reducing longrun strike costs, would raise strike durations. Furthermore, to the extent that costly replacement signals information, then banning replacements would increase uncertainty and lengthen strike durations.

At first glance, this increase in strike activity seems to be inconsistent with the joint-cost hypothesis (Kennan 1980; Reder and Neumann 1980), which posits that strike activity should decrease when the joint costs of a strike increase. However, while the ban increases the cost of a strike to the firm, it reduces the cost of a strike to the union because the strike does not include a risk of replacement. Hence, the joint-cost hypothesis is ambiguous with respect to the expected impact on strike activity of a ban on strike replacements. 


\section{Impact of Labor Policy on Welfare}

Table 6 summaries our results on wages and strike activity by pulling together the results from the most parsimonious specifications from the previous tables. Based on these estimates, we can calculate the welfare consequences of the various labor policies (Table 7). Following Currie and McConnell (1991), the calculations of strike cost are based on the conservative assumption that the joint cost of the strike is the lost wages, which amounts to $\$ 100$ per person-day. Others have estimated strike costs to be much higher. For example, Imberman (1979), in an accounting study of strike costs at 28 firms, estimated the firms' strike costs to be about $\$ 900$ (1993 Canadian dollars) per person-day.

The effect a policy has on strike costs reflects both changes in strike incidence and strike duration. From columns (3) and (4) of Table 6, we calculate strike incidence and strike duration both with and without each policy. The unconditional strike duration (that is, the average strike duration per contract negotiation) is then calculated as the product of strike incidence and strike duration. For our sample, the mean unconditional duration is 9.7 days. The change in unconditional duration, then, is the difference in the unconditional strike duration with and without the policy. The change in strike cost associated with a policy is the change in unconditional strike duration times the mean cost per day of strike.

The wage gain from a policy is measured as the change in the wage bill with and without the policy over the life of the contract. To the extent current wage changes are carried over to future contracts, this is an understatement of the wage gain associated with the policy. In calculating the net gain from a policy for the union and firm, we assume that the strike cost is split equally between the two parties. Hence, the union's net gain is the wage gain less half the strike cost, and the firm's net loss is the wage gain plus half the strike cost.

Of all the policy variables, the ban on replacement workers is associated with the largest strike costs, due to the ban's large positive effect on strike incidence and strike duration. Unconditional strike duration increases by 15.9 days, an increase of $160 \%$. The estimated cost of the ban is $\$ 2.03$ million (1993 Canadian dollars) per contract negotiation. Despite this large cost, the average wage gain is so large ( $\$ 9.42$ million) that the union is still made much better off with a ban on replacements (the firm is much worse off). Hence, it is not surprising that unions lobbied hard for this legislation.

Banning strike replacements has significant costs in terms of increased strike activity, and implies an even larger wealth transfer from firms to union workers. Offsetting at least some of the larger strike cost from increased strike activity is a reduction in strike related violence. Strike violence tends to escalate when replacements are used, since once replaced, 
TABLE 5 - Estimates of THE IMPACT OF LABOR POLICY ON STRIKe DURATION

\begin{tabular}{|c|c|c|c|c|}
\hline \multirow[b]{2}{*}{ Variable } & \multicolumn{2}{|c|}{$\begin{array}{l}\text { log Strike Duration } \\
\text { (large strikes) }\end{array}$} & \multicolumn{2}{|c|}{$\begin{array}{l}\log \text { Strike Duration } \\
\text { (all strikes) }\end{array}$} \\
\hline & (1) & (2) & (3) & $(4)^{a}$ \\
\hline \multicolumn{5}{|l|}{ Policy variables: } \\
\hline Conciliation officer & $\begin{array}{l}0.005 \\
(0.02)\end{array}$ & $\begin{array}{c}0.003 \\
(0.01)\end{array}$ & $\begin{array}{l}0.096 \\
(1.56)\end{array}$ & $\begin{array}{l}0.104^{*} \\
(1.71)\end{array}$ \\
\hline Conciliation officer and board & $\begin{array}{l}0.247 \\
(0.45)\end{array}$ & $\begin{array}{l}0.162 \\
(0.29)\end{array}$ & $\begin{array}{c}-0.008 \\
(0.07)\end{array}$ & $\begin{array}{c}-0.000 \\
(0.00)\end{array}$ \\
\hline Cooling-off period (days) & $\begin{array}{c}0.030 \\
(0.90)\end{array}$ & $\begin{array}{c}0.027 \\
(0.81)\end{array}$ & $\begin{array}{c}-0.004 \\
(0.58)\end{array}$ & $\begin{array}{c}-0.005 \\
(0.67)\end{array}$ \\
\hline Mandatory strike vote & $\begin{array}{c}-0.329 \\
(0.80)\end{array}$ & $\begin{array}{c}-0.337 \\
(0.82)\end{array}$ & $\begin{array}{l}-0.232^{* *} \\
(2.81)\end{array}$ & $\begin{array}{l}-0.235^{* *} \\
(2.88)\end{array}$ \\
\hline Employer initiated vote option & $\begin{array}{l}0.009 \\
(0.03)\end{array}$ & $\begin{array}{c}-0.029 \\
(0.10)\end{array}$ & $\begin{array}{c}-0.047 \\
(0.58)\end{array}$ & $\begin{array}{c}-0.043 \\
(0.53)\end{array}$ \\
\hline Compulsory dues checkoff & $\begin{array}{c}-0.043 \\
(0.17)\end{array}$ & $\begin{array}{r}0.051 \\
(0.20)\end{array}$ & $\begin{array}{c}-0.012 \\
(0.16)\end{array}$ & $\begin{array}{c}-0.011 \\
(0.15)\end{array}$ \\
\hline Prohibit replacement workers & $\begin{array}{c}0.469 \\
(0.96)\end{array}$ & $\begin{array}{c}0.402 \\
(0.83)\end{array}$ & $\begin{array}{l}0.344^{* *} \\
(3.06)\end{array}$ & $\begin{array}{l}0.363^{* *} \\
(3.26)\end{array}$ \\
\hline Right to reopen negotiations & $\begin{array}{l}0.109 \\
(0.25)\end{array}$ & $\begin{array}{l}0.112 \\
(0.26)\end{array}$ & $\begin{array}{l}-0.369 * * \\
(3.98)\end{array}$ & $\begin{array}{l}-0.369^{* *} \\
(4.02)\end{array}$ \\
\hline Reopen if technological change & $\begin{array}{c}-0.275 \\
(1.01)\end{array}$ & $\begin{array}{c}-0.268 \\
(0.99)\end{array}$ & $\begin{array}{c}-0.017 \\
(0.23)\end{array}$ & $\begin{array}{r}-0.017 \\
(0.23)\end{array}$ \\
\hline \multicolumn{5}{|l|}{ Other variables: } \\
\hline Anti-inflation board & $\begin{array}{r}0.101 \\
(0.54)\end{array}$ & $\begin{array}{l}0.099 \\
(0.53)\end{array}$ & $\begin{array}{c}0.009 \\
(0.19)\end{array}$ & $\begin{array}{l}0.008 \\
(0.16)\end{array}$ \\
\hline COLA in prior contract & $\begin{array}{l}0.029 \\
(0.24)\end{array}$ & $\begin{array}{l}0.045 \\
(0.37)\end{array}$ & & \\
\hline Contract duration (log days) & $\begin{array}{l}0.497^{* *} \\
(3.43)\end{array}$ & $\begin{array}{l}0.527 * * \\
(3.63)\end{array}$ & & \\
\hline Bargaining unit size (log) & $\begin{array}{c}-0.210^{* *} \\
(3.52)\end{array}$ & $\begin{array}{c}-0.224^{* *} \\
(3.75)\end{array}$ & $\begin{array}{l}-0.108^{* *} \\
(11.49)\end{array}$ & $\begin{array}{l}-0.106^{* *} \\
(11.36)\end{array}$ \\
\hline Prior real percentage wage change & $\begin{array}{c}-0.026^{* *} \\
(2.04)\end{array}$ & $\begin{array}{c}-0.024^{*} \\
(1.92)\end{array}$ & & \\
\hline Provincial unemployment rate & $\begin{array}{c}-2.779 \\
(0.96)\end{array}$ & $\begin{array}{c}-2.638 \\
(0.92)\end{array}$ & $\begin{array}{r}-0.593 \\
(0.74)\end{array}$ & $\begin{array}{c}-0.662 \\
(0.83)\end{array}$ \\
\hline Percentage change in employment & $\begin{array}{c}-0.001 \\
(0.43)\end{array}$ & $\begin{array}{c}-0.000 \\
(0.04)\end{array}$ & & \\
\hline Provincial real manufacturing wage (log) & $\begin{array}{l}4.028 * * \\
(2.69)\end{array}$ & $\begin{array}{l}4.402^{* *} \\
(2.94)\end{array}$ & $\begin{array}{c}-0.425 \\
(1.54)\end{array}$ & $\begin{array}{c}-0.427 \\
(1.56)\end{array}$ \\
\hline
\end{tabular}


TABLE $5-$ Continued

\begin{tabular}{|c|c|c|c|c|}
\hline \multirow[b]{2}{*}{ Variable } & \multicolumn{2}{|c|}{$\begin{array}{l}\log \text { Strike Duration } \\
\text { (large strikes) }\end{array}$} & \multicolumn{2}{|c|}{$\begin{array}{l}\log \text { Strike Duration } \\
\text { (all strikes) }\end{array}$} \\
\hline & (1) & (2) & (3) & $(4)^{a}$ \\
\hline Conciliation used in prior contract & $\begin{array}{r}0.061 \\
(0.52)\end{array}$ & $\begin{array}{l}0.064 \\
(0.56)\end{array}$ & & \\
\hline Mediation used in prior contract & $\begin{array}{c}-0.070 \\
(0.41)\end{array}$ & $\begin{array}{c}-0.047 \\
(0.28)\end{array}$ & & \\
\hline Wage is primary issue & $\begin{array}{l}0.431^{* *} \\
(3.87)\end{array}$ & $\begin{array}{l}0.420^{* *} \\
(3.79)\end{array}$ & $\begin{array}{l}0.763^{* *} \\
(30.70)\end{array}$ & $\begin{array}{l}0.760 * * \\
(30.93)\end{array}$ \\
\hline Lockout & $\begin{array}{l}0.333^{*} \\
(1.77)\end{array}$ & $\begin{array}{l}0.330^{*} \\
(1.77)\end{array}$ & $\begin{array}{l}0.414^{* *} \\
(9.02)\end{array}$ & $\begin{array}{l}0.402^{* *} \\
(8.87)\end{array}$ \\
\hline Rotating strike & $\begin{array}{l}0.451^{*} \\
(1.89)\end{array}$ & $\begin{array}{l}0.472^{* *} \\
(1.98)\end{array}$ & $\begin{array}{l}0.510^{* *} \\
(3.80)\end{array}$ & $\begin{array}{l}0.512^{* *} \\
(3.85)\end{array}$ \\
\hline Strike in prior contract & $\begin{array}{l}0.370^{* *} \\
(2.82)\end{array}$ & & & \\
\hline $\begin{array}{l}\text { Indicators for prior strike duration: } \\
\text { (a) } 1-7 \text { days }\end{array}$ & & $\begin{array}{l}0.456^{* *} \\
(2.20)\end{array}$ & & \\
\hline (b) 8-28 days (28\%) & & $\begin{array}{l}0.509 * * \\
(2.79)\end{array}$ & & \\
\hline (c) $29-49$ days $(18 \%)$ & & $\begin{array}{l}0.206 \\
(0.88)\end{array}$ & & \\
\hline (d) $50-98$ days $(20 \%)$ & & $\begin{array}{c}-0.434 \\
(1.50)\end{array}$ & & \\
\hline (e) $99-147$ days $(10 \%)$ & & $\begin{array}{r}0.741 \\
(1.58)\end{array}$ & & \\
\hline (f) $148+$ days $(10 \%)$ & & $\begin{array}{l}0.867^{* *} \\
(2.57)\end{array}$ & & \\
\hline $\begin{array}{l}\text { Controls (number of variables): Region (5), } \\
\text { Season (3), Union (5), Time (3), Industry (32) }\end{array}$ & yes & yes & yes & yes \\
\hline Sample size & 708 & 708 & 12929 & 12929 \\
\hline F-test for policy variables ${ }^{b}$ & $\begin{array}{l}0.75 \\
{[0.6606]}\end{array}$ & $\begin{array}{l}0.61 \\
{[0.7921]}\end{array}$ & $\begin{array}{l}3.52 \\
{[0.0002]}\end{array}$ & $\begin{array}{l}3.68 \\
{[0.0001]}\end{array}$ \\
\hline$R^{2}$ & 0.268 & 0.283 & 0.151 & 0.152 \\
\hline
\end{tabular}

Notes: t-statistics in parentheses. Contract specific variables are missing from (3) and (4), since they are not included in the all strikes data set.

${ }^{a}$ Strike durations longer than one year truncated at 365 days.

${ }^{b}$ F-test for the joint significance of the policy variables. Probability values in brackets.

*Statistically significant at 0.10 level. ${ }^{* *}$ Statistically significant at 0.05 level. 
TABle 6 - Estimates of THE IMPACT OF LABOR POLICY ON WAGES AND STRIKe ACTIVITY

\begin{tabular}{|c|c|c|c|c|c|}
\hline \multirow[b]{2}{*}{ Variable } & \multicolumn{2}{|c|}{$\begin{array}{c}\text { log Real Wage } \\
\text { Table } 3\end{array}$} & \multirow{2}{*}{$\begin{array}{c}\text { Strike } \\
\text { Incidence } \\
\text { Table } 4 \\
(3)^{a}\end{array}$} & \multicolumn{2}{|c|}{$\begin{array}{c}\text { log Strike Duration } \\
\text { Table } 5\end{array}$} \\
\hline & (1) & (2) & & $\begin{array}{l}\text { large } \\
\text { strikes } \\
\quad(4)\end{array}$ & $\begin{array}{c}\text { all } \\
\text { strikes } \\
(5)\end{array}$ \\
\hline \multicolumn{6}{|l|}{ Policy variables: } \\
\hline Conciliation officer & $\begin{array}{c}-0.000 \\
(0.03)\end{array}$ & $\begin{array}{l}0.013^{* *} \\
(2.82)\end{array}$ & $\begin{array}{r}-0.013 \\
(0.42)\end{array}$ & $\begin{array}{l}0.003 \\
(0.01)\end{array}$ & $\begin{array}{l}0.096 \\
(1.56)\end{array}$ \\
\hline Conciliation officer and board & $\begin{array}{r}0.030 \\
(1.37)\end{array}$ & $\begin{array}{l}0.019 * * \\
(2.28)\end{array}$ & $\begin{array}{c}-0.022 \\
(0.37)\end{array}$ & $\begin{array}{l}0.162 \\
(0.29)\end{array}$ & $\begin{array}{c}-0.008 \\
(0.07)\end{array}$ \\
\hline Cooling-off period (days) & $\begin{array}{l}-0.005^{* *} \\
(3.11)\end{array}$ & $\begin{array}{l}-0.003^{* *} \\
(4.93)\end{array}$ & $\begin{array}{c}-0.003 \\
(0.60)\end{array}$ & $\begin{array}{r}0.027 \\
(0.81)\end{array}$ & $\begin{array}{c}-0.004 \\
(0.58)\end{array}$ \\
\hline Mandatory strike vote & $\begin{array}{c}-0.016 \\
(0.96)\end{array}$ & $\begin{array}{c}0.005 \\
(0.79)\end{array}$ & $\begin{array}{c}-0.062 \\
(1.58)\end{array}$ & $\begin{array}{c}-0.337 \\
(0.82)\end{array}$ & $\begin{array}{c}-0.232^{* *} \\
(2.81)\end{array}$ \\
\hline Employer initiated vote option & $\begin{array}{l}0.059 * * \\
(3.76)\end{array}$ & $\begin{array}{l}0.076^{* *} \\
(13.01)\end{array}$ & $\begin{array}{r}0.047 \\
(1.13)\end{array}$ & $\begin{array}{c}-0.029 \\
(0.10)\end{array}$ & $\begin{array}{c}-0.047 \\
(0.58)\end{array}$ \\
\hline Compulsory dues checkoff & $\begin{array}{l}-0.048^{* *} \\
(3.60)\end{array}$ & $\begin{array}{l}-0.031^{* *} \\
(6.18)\end{array}$ & $\begin{array}{l}-0.069 * * \\
(2.56)\end{array}$ & $\begin{array}{r}0.051 \\
(0.20)\end{array}$ & $\begin{array}{c}-0.012 \\
(0.16)\end{array}$ \\
\hline Prohibit replacement workers & $\begin{array}{l}0.106^{* *} \\
(4.63)\end{array}$ & $\begin{array}{l}0.040^{* *} \\
(4.60)\end{array}$ & $\begin{array}{l}0.159 * * \\
(1.99)\end{array}$ & $\begin{array}{c}0.402 \\
(0.83)\end{array}$ & $\begin{array}{l}0.344^{* *} \\
(3.06)\end{array}$ \\
\hline Right to reopen negotiations & $\begin{array}{c}0.021 \\
(1.10)\end{array}$ & $\begin{array}{c}-0.006 \\
(0.79)\end{array}$ & $\begin{array}{c}-0.072^{*} \\
(1.74)\end{array}$ & $\begin{array}{c}0.112 \\
(0.26)\end{array}$ & $\begin{array}{c}-0.369^{* *} \\
(3.98)\end{array}$ \\
\hline Reopen if technological change & $\begin{array}{l}0.030 * * \\
(2.01)\end{array}$ & $\begin{array}{l}0.014^{* *} \\
(2.54)\end{array}$ & $\begin{array}{l}0.084^{*} \\
(1.86)\end{array}$ & $\begin{array}{c}-0.268 \\
(0.99)\end{array}$ & $\begin{array}{c}-0.017 \\
(0.23)\end{array}$ \\
\hline \multicolumn{6}{|l|}{ Other variables: } \\
\hline Anti-inflation board & $\begin{array}{c}-0.010 \\
(1.06)\end{array}$ & $\begin{array}{l}-0.038^{* *} \\
(10.45)\end{array}$ & $\begin{array}{l}-0.044^{* *} \\
(2.04)\end{array}$ & $\begin{array}{r}0.099 \\
(0.53)\end{array}$ & $\begin{array}{l}0.009 \\
(0.19)\end{array}$ \\
\hline COLA clause in contract ${ }^{b}$ & $\begin{array}{l}0.073^{* *} \\
(10.77)\end{array}$ & $\begin{array}{l}0.026 * * \\
(9.96)\end{array}$ & $\begin{array}{c}-0.007 \\
(0.46)\end{array}$ & $\begin{array}{l}0.045 \\
(0.37)\end{array}$ & \\
\hline Contract duration (log days) & $\begin{array}{l}0.025^{* *} \\
(3.18)\end{array}$ & $\begin{array}{l}0.000 \\
(0.03)\end{array}$ & $\begin{array}{l}0.166^{* *} \\
(6.00)\end{array}$ & $\begin{array}{l}0.527^{* *} \\
(3.63)\end{array}$ & \\
\hline Bargaining unit size (log) & $\begin{array}{l}0.030^{* *} \\
(8.08)\end{array}$ & $\begin{array}{l}0.000 \\
(0.56)\end{array}$ & $\begin{array}{l}0.033^{* *} \\
(3.55)\end{array}$ & $\begin{array}{l}-0.224^{* *} \\
(3.75)\end{array}$ & $\begin{array}{l}-0.108^{* *} \\
(11.49)\end{array}$ \\
\hline Real previous wage $(\log )^{\mathcal{C}}$ & & $\begin{array}{c}0.915^{* *} \\
(179.02)\end{array}$ & $\begin{array}{c}-0.002 \\
(1.58)\end{array}$ & $\begin{array}{c}-0.024^{*} \\
(1.92)\end{array}$ & \\
\hline Provincial unemployment rate & $\begin{array}{r}0.143 \\
(0.91)\end{array}$ & $\begin{array}{c}-0.029 \\
(0.50)\end{array}$ & $\begin{array}{l}-0.163^{* *} \\
(2.16)\end{array}$ & $\begin{array}{c}-2.638 \\
(0.92)\end{array}$ & $\begin{array}{c}-0.593 \\
(0.74)\end{array}$ \\
\hline Percentage change in employment & & & $\begin{array}{c}0.000^{*} \\
(1.65)\end{array}$ & $\begin{array}{c}-0.000 \\
(0.04)\end{array}$ & \\
\hline $\begin{array}{r}\text { Provincial real manufacturing } \\
\text { wage }(\log )\end{array}$ & $\begin{array}{l}0.533^{* *} \\
(7.26)\end{array}$ & $\begin{array}{l}-0.052^{*} \\
(1.88)\end{array}$ & $\begin{array}{c}-0.134 \\
(1.27)\end{array}$ & $\begin{array}{l}4.402 * * \\
(2.94)\end{array}$ & $\begin{array}{c}-0.425 \\
(1.54)\end{array}$ \\
\hline $\begin{array}{r}\text { Fraction of bargaining unit on } \\
\text { strike }\end{array}$ & $\begin{array}{l}-0.081^{* *} \\
(3.46)\end{array}$ & $\begin{array}{l}-0.028^{* *} \\
(3.23)\end{array}$ & & & \\
\hline
\end{tabular}


TABLE 6 - Continued

\begin{tabular}{|c|c|c|c|c|c|}
\hline \multirow[b]{2}{*}{ Variable } & \multicolumn{2}{|c|}{$\begin{array}{c}\text { log Real Wage } \\
\text { Table } 3\end{array}$} & \multirow{2}{*}{$\begin{array}{c}\text { Strike } \\
\text { Incidence } \\
\text { Table } 4 \\
(3)^{a}\end{array}$} & \multicolumn{2}{|c|}{$\begin{array}{c}\log \text { Strike Duration } \\
\text { Table } 5\end{array}$} \\
\hline & (1) & (2) & & $\begin{array}{l}\text { large } \\
\text { strikes } \\
(4)\end{array}$ & $\begin{array}{c}\text { all } \\
\text { strikes } \\
\text { (5) }\end{array}$ \\
\hline Conciliation used & $\begin{array}{l}0.012^{*} \\
(1.86)\end{array}$ & $\begin{array}{r}0.004 \\
(1.54)\end{array}$ & $\begin{array}{l}0.090^{* *} \\
(4.94)\end{array}$ & $\begin{array}{c}0.064 \\
(0.56)\end{array}$ & \\
\hline Mediation used & $\begin{array}{l}0.023^{* *} \\
(2.49)\end{array}$ & $\begin{array}{l}0.003 \\
(0.87)\end{array}$ & $\begin{array}{l}0.100^{* *} \\
(3.70)\end{array}$ & $\begin{array}{c}-0.047 \\
(0.28)\end{array}$ & \\
\hline Wage is primary issue & $\begin{array}{c}0.008 \\
(0.49)\end{array}$ & $\begin{array}{r}0.002 \\
(0.32)\end{array}$ & & $\begin{array}{l}0.420 * * \\
(3.79)\end{array}$ & $\begin{array}{l}0.763^{* *} \\
(30.70)\end{array}$ \\
\hline Lockout & $\begin{array}{c}-0.020 \\
(0.76)\end{array}$ & $\begin{array}{l}-0.030 * * \\
(3.02)\end{array}$ & & $\begin{array}{l}0.330^{*} \\
(1.77)\end{array}$ & $\begin{array}{l}0.414^{* *} \\
(9.02)\end{array}$ \\
\hline Rotating strike & $\begin{array}{l}0.021 \\
(0.70)\end{array}$ & $\begin{array}{c}-0.011 \\
(0.97)\end{array}$ & & $\begin{array}{l}0.472^{* *} \\
(1.98)\end{array}$ & $\begin{array}{l}0.510^{* *} \\
(3.80)\end{array}$ \\
\hline $\begin{array}{l}\text { Indicators for strike duration: }{ }^{d} \\
\text { (a) } 1-7 \text { days } \quad(14 \%)\end{array}$ & $\begin{array}{l}0.078 * * \\
(3.04)\end{array}$ & $\begin{array}{l}0.019^{*} \\
(1.95)\end{array}$ & $\begin{array}{l}0.160 * * \\
(3.78)\end{array}$ & $\begin{array}{l}0.456^{* *} \\
(2.20)\end{array}$ & \\
\hline (b) 8-28 days (27\%) & $\begin{array}{l}0.088^{* *} \\
(3.53)\end{array}$ & $\begin{array}{l}0.035^{* *} \\
(3.71)\end{array}$ & $\begin{array}{l}0.115^{* *} \\
(3.47)\end{array}$ & $\begin{array}{l}0.509^{* *} \\
(2.79)\end{array}$ & \\
\hline (c) $29-49$ days $(19 \%)$ & $\begin{array}{l}0.084 * * \\
(3.13)\end{array}$ & $\begin{array}{l}0.034^{* *} \\
(3.37)\end{array}$ & $\begin{array}{l}0.050 \\
(1.36)\end{array}$ & $\begin{array}{l}0.206 \\
(0.88)\end{array}$ & \\
\hline (d) $50-98$ days $(21 \%)$ & $\begin{array}{l}0.072 * * \\
(2.66)\end{array}$ & $\begin{array}{l}0.052^{* *} \\
(5.09)\end{array}$ & $\begin{array}{l}-0.069 * * \\
(2.26)\end{array}$ & $\begin{array}{c}-0.434 \\
(1.50)\end{array}$ & \\
\hline (e) $99-147$ days $(10 \%)$ & $\begin{array}{l}0.109 * * \\
(3.54)\end{array}$ & $\begin{array}{l}0.053^{* *} \\
(4.62)\end{array}$ & $\begin{array}{l}-0.106^{* *} \\
(2.60)\end{array}$ & $\begin{array}{l}0.741 \\
(1.58)\end{array}$ & \\
\hline (f) $148+$ days $\quad(9 \%)$ & $\begin{array}{r}0.050 \\
(1.61)\end{array}$ & $\begin{array}{l}0.042^{* *} \\
(3.61)\end{array}$ & $\begin{array}{r}0.023 \\
(0.49) \\
\end{array}$ & $\begin{array}{l}0.867^{* *} \\
(2.57)\end{array}$ & \\
\hline $\begin{array}{l}\text { F-test for group: }{ }^{e} \quad \text { Policy (9) } \\
\text { (number of variables) }\end{array}$ & $\begin{array}{l}7.68 \\
{[0.0000]}\end{array}$ & $\begin{array}{l}22.75 \\
{[0.0000]}\end{array}$ & $\begin{array}{l}11.99 \\
{[0.2138]}\end{array}$ & $\begin{array}{l}0.61 \\
{[0.7921]}\end{array}$ & $\begin{array}{l}3.52 \\
{[0.0002]}\end{array}$ \\
\hline Region (5) & $\begin{array}{l}5.83 \\
{[0.0000]}\end{array}$ & $\begin{array}{l}4.60 \\
{[0.0003]}\end{array}$ & $\begin{array}{l}34.53 \\
{[0.0000]}\end{array}$ & $\begin{array}{l}2.71 \\
{[0.0196]}\end{array}$ & $\begin{array}{l}10.44 \\
{[0.0000]}\end{array}$ \\
\hline Season (3) & $\begin{array}{l}13.71 \\
{[0.0000]}\end{array}$ & $\begin{array}{l}2.12 \\
{[0.0949]}\end{array}$ & $\begin{array}{l}2.54 \\
{[0.4676]}\end{array}$ & $\begin{array}{l}0.93 \\
{[0.4237]}\end{array}$ & $\begin{array}{l}3.79 \\
{[0.0099]}\end{array}$ \\
\hline Union (5) & $\begin{array}{l}25.89 \\
{[0.0000]}\end{array}$ & $\begin{array}{l}2.55 \\
{[0.0260]}\end{array}$ & $\begin{array}{l}44.54 \\
{[0.0000]}\end{array}$ & $\begin{array}{l}2.85 \\
{[0.0148]}\end{array}$ & $\begin{array}{l}4.31 \\
{[0.0006]}\end{array}$ \\
\hline Time (3) & $\begin{array}{l}9.24 \\
{[0.0000]}\end{array}$ & $\begin{array}{l}6.17 \\
{[0.0003]}\end{array}$ & $\begin{array}{l}17.64 \\
{[0.0005]}\end{array}$ & $\begin{array}{l}2.26 \\
{[0.0807]}\end{array}$ & $\begin{array}{c}3.57 \\
{[0.0134]}\end{array}$ \\
\hline Industry (32) & $\begin{array}{l}113.19 \\
{[0.0000]}\end{array}$ & $\begin{array}{l}5.13 \\
{[0.0000]}\end{array}$ & $\begin{array}{l}78.42 \\
{[0.0000]}\end{array}$ & $\begin{array}{l}2.07 \\
{[0.0006]}\end{array}$ & $\begin{array}{l}4.89 \\
{[0.0000]}\end{array}$ \\
\hline Sample size & 5345 & 5345 & 4364 & 708 & 12929 \\
\hline$R^{2}$ & 0.590 & 0.942 & & 0.283 & 0.151 \\
\hline
\end{tabular}

Notes: t-statistics in parentheses, except (3) which gives z-statistics.

${ }^{a}$ Change in strike probability per unit increase (evaluated at the mean strike probability of 0.16 ).

${ }^{b}$ For (3) and (4), variable is COLA clause in prior contract.

${ }^{c}$ For (3) and (4), variable is prior real percentage wage change.

${ }^{d}$ For (3) and (4), variables indicate strike duration in prior contract.

${ }^{e}$ F-test $\left(\chi^{2}\right.$-test in (3)) for joint significance of group of variables. Probability values in brackets.

*Statistically significant at 0.10 level. ${ }^{* *}$ Statistically significant at 0.05 level. 
TABLE 7 - EsTIMATES OF THE IMPACT OF LABOR POLICY ON WELFARE

\begin{tabular}{|c|c|c|c|c|c|c|}
\hline \multirow[b]{2}{*}{ Policy variable } & \multirow{2}{*}{$\begin{array}{c}\text { Percent } \\
\text { change in } \\
\text { wage }\end{array}$} & \multirow{2}{*}{$\begin{array}{l}\text { Change in } \\
\text { unconditional } \\
\text { duration (days) }\end{array}$} & \multicolumn{4}{|c|}{ Million June 1993 Canadian dollars per contract } \\
\hline & & & $\begin{array}{c}\text { Strike } \\
\text { cost }\end{array}$ & $\begin{array}{l}\text { Wage } \\
\text { gain }\end{array}$ & $\begin{array}{l}\text { Union } \\
\text { net gain }\end{array}$ & $\begin{array}{c}\text { Firm } \\
\text { net gain }\end{array}$ \\
\hline Conciliation officer only & 0.0 & -0.7 & -0.09 & 0.00 & 0.05 & 0.05 \\
\hline Conciliation officer and board & 3.0 & 0.1 & 0.01 & 2.67 & 2.66 & -2.67 \\
\hline Cooling-off period (weeks) & -3.5 & 1.0 & 0.13 & -3.11 & -3.18 & 3.04 \\
\hline Mandatory strike vote & -1.6 & -6.6 & -0.84 & -1.42 & -1.00 & 1.84 \\
\hline Employer initiated vote option & 5.9 & 2.4 & 0.31 & 5.24 & 5.09 & -5.40 \\
\hline Compulsory dues checkoff & -4.8 & -3.6 & -0.46 & -4.26 & -4.04 & 4.49 \\
\hline Prohibit replacement workers & 10.6 & 15.9 & 2.03 & 9.42 & 8.40 & -10.43 \\
\hline Right to reopen negotiations & 2.1 & -3.2 & -0.40 & 1.87 & 2.07 & -1.66 \\
\hline Reopen if technological change & 3.0 & 1.6 & 0.21 & 2.67 & 2.56 & -2.77 \\
\hline
\end{tabular}

Notes: Based on a mean strike incidence of 0.165 , a mean strike duration $(D)$ of 59 days, a mean contract duration $(\ell)$ of 822 days, a mean real wage $(w)$ of $\$ 13.81$ (June 1993 Canadian dollars), a mean bargaining unit size $(n)$ of 1531 workers, a mean person-days lost due to the strike $(d)$ of 76 thousand days, a mean number of hours worked per week $(h)$ of 36 , and a mean loss per strike $(L=w \cdot d \cdot h / 5)$ of $\$ 7.50$ million, equal to the lost wages. All of the above constants are calculated from our sample, except the mean number of hours worked per week, which is the average hours worked per week of persons in manufacturing industries from 1967 to 1991 (Cansim code 1191206). The proportionate change in the real wage $W_{i}$ is taken from Table 6 , column (1); the change in unconditional strike duration $D_{i}$ is calculated from columns (3) and (4) of Table 6, as described in the text; strike cost $=C_{i}=L \cdot D_{i} / D$; wage gain $=G_{i}=W_{i} \cdot n \cdot \ell \cdot h / 5$; union net gain $=G_{i}-C_{i} / 2$; firm net gain $=-G_{i}-C_{i} / 2$. 
violence is often the only means left for the union to put pressure on the firm. (Our data on U.S. strikes supports this claim; we do not have data on the extent of violence in Canadian strikes.) One's view on the policy question to ban strike replacements, then, should hinge on (1) the desirability of transferring wealth from firms to union workers, (2) the importance of the increase in strike costs due to greater strike activity, and (3) the importance of the reduction in strike related violence stemming from a ban on replacements. Although this analysis cannot answer the policy question, it certainly can inform the debate.

\section{Conclusion}

We estimate the effects of labor policy on wages and strike activity using a Canadian sample of 5,819 private sector contract negotiations involving 500 or more workers from January 1967 to March 1993. We interpret our estimates in light of private information theories of wage bargaining.

Our analysis confirms Card's (1990) finding that there is no tendency for wages to fall with strike duration. Indeed, we find that wages increase with strike duration. This is inconsistent with the simplest theory in which the union is uncertain about the firm's willingness to pay. However, once the model is expanded to allow firm uncertainty about the union's willingness to accept, wages can increase with strike duration.

Compulsory conciliation and cooling-off periods are found to be ineffective at reducing strike activity. These policies were introduced with the intent to reduce strike activity by facilitating communication and hence reducing uncertainty. Their failure may mean that conciliation and cooling-off periods do not reduce uncertainty. Alternatively, it may be that the parties voluntarily adopt dispute resolution procedures, whenever they are effective, so requiring them does not reduce dispute costs.

The two policies most effective at reducing strike activity are the mandatory strike vote and the right to reopen negotiations. Requiring the rank and file to approve the strike limits the union leader's ability to call a strike. Hence, strike incidence should fall. The right to reopen negotiations makes the current contract less important. The parties can settle some disagreements after more uncertainty is resolved, thus reducing strike activity.

The clearest test of the theory is with respect to the ban on replacement workers. The theory makes unambiguous predictions about how such a ban effects wages and strike activity. The ban of replacements improves the union's strike payoff relative to the firm's; hence, wages should increase. This improvement in the attractiveness of the union's strike threat relative to other means of applying pressure on the firm means that the strike threat should be adopted more often by the union, increasing strike incidence. Strike duration should increase also, since the ban effectively increases uncertainty by eliminating an upper 
bound on the firm's willingness to pay and an additional means of signaling information. Duration also should increase because the ban makes it less likely that strike costs fall over time. Consistent with this theory, we find that the ban on replacements does significantly increase wages, strike incidence, and strike duration. Wages are 10.6 percent higher with the ban, strike incidence doubles, and strike duration increases by about 40 percent.

Since conducting this study, we became aware of similar work by Budd (1993) which also deals with the impact, on wages and strike activity, of Quebec's ban on replacement workers. Direct comparison between the two studies is difficult, however, because Budd's results for the ban on replacement workers are sensitive to specification, in particular whether there are controls for industry and province or bargaining-pair fixed effects. Furthermore, Budd's analysis was for a shorter time period (1966 to 1985) compared to ours (1967 to 1993). This may be critical since his analysis only covers about half of the 16 year time period since 1977 when Quebec's legislation was in place. In addition, Budd's analysis covers only manufacturing, while ours covers both manufacturing and non-manufacturing contracts; his analysis includes only two of our eight policy variables; and his analysis includes about half of our nonpolicy control variables.

In spite of these differences, our results are fairly similar to those based on what Budd indicates as his preferred specification. Specifically, when his preferred specification is used, he finds the ban on replacement workers to be associated with significantly higher wage changes and longer strike durations (reduced conditional settlement probabilities). Our major difference is with respect to the impact on strike incidence. He finds a positive effect in all specifications, but one that is statistically insignificant when controls are added for province and bargaining-pair fixed effects.

Our results that the legislative ban on replacement workers is associated with significantly higher wages and increased strike incidence and duration, therefore, should be interpreted with the qualification of Budd's analysis. Furthermore, the evidence for this particular variable is based almost entirely on the experience of a single province, Quebec, which adopted the replacement ban in 1977. Clearly, the emerging experience of Ontario and British Columbia, where the policy was only recently adopted, will be important in subsequent testing of this important relationship.

Subject to these qualifications, our main conclusions are: (1) the legislative ban on replacement workers is associated with increased wages as well as increased strike incidence and duration; (2) the increased wages and higher strike costs make employers worse off, but union workers are better off because the higher wages more than offset their higher strike costs; (3) the overall welfare implications of a ban on replacement workers cannot be determined without further information on such factors as reductions in violence that may be 
associated with the ban on replacements; (4) the mandatory strike vote and the right to reopen negotiations are the two policies most effective in reducing strike incidence and duration; (5) settlement wages tend not to fall with increased strike duration. 


\section{Data Definitions and Sources}

The data comes from three main sources:

1. Wage file. Labour Canada, Major Wage Settlements data base. Includes settlements with at least 500 workers. For settlements from 1967 to 1977 , the data was provided on a tape labeled "J90Tape". For settlements from 1978 to March 1993, the data was provided on a diskette. Although the bargaining unit identifiers changed after 1977 , a link file was included that permitted the linking of the pre-1978 tape data with the post-1977 identifiers. Data from the tape and diskette overlapped for the years 1978 to 1985 . As a consistency check, we compared the two data sources for these years. The two sources were nearly identical (once minor coding changes were accounted for), except that a miscoding of the "settlement stage" variable on the tape was corrected on the diskette. The coding error, reported in Card (1990), exists on the tape for the years 1979 to 1981 . It does not occur during the years for which we use the data from the tape.

2. Work Stoppage file. Labour Canada, Work Stoppage data base, provided on diskettes. Includes all Canadian work stoppages that began between 1966 to April 1993. The procedure for linking the Wage file and the Work Stoppage file are described below.

3. Cansim. Statistics Canada, Cansim data base, down-loaded from epas.utoronto.ca. Includes aggregate Canadian and provincial economic data through May 1993.

Real wage

Effective wage at the end of the contract deflated by the 1981 Canadian CPI. Source: Wage file.

\section{Strike occurred}

Work stoppage occurred before the parties settled. If the Wage file indicated a strike occurred, but there was no corresponding record in the Work Stoppage file, then the record was

\section{Appendix}

dropped. This was the case for seven out of the 888 strikes $(0.8 \%)$. Source: Wage file and Work Stoppage file.

\section{Strike dunation}

The number of calendar days between the beginning and the end of the strike. Source:

Work Stoppage file.

Policy rariables

All nine policy variables indicate whether a particular policy was in effect at the time of settlement, monthly by province. See the text (Section II) for details. Source: Gunderson, Kervin, and Reid (1988), Labour Canada, Industrial Relations Legislation in Canada and CCH Canadian Ltd., Canadian Labour Law Reporter.

\section{Anti-inflation board}

Wage and price controls in effect at the contract expiration, monthly by province. Source: AntiInflation Board, Chronicles of the Anti-Inflation Board.

\section{Contract duration}

The number of calendar days between the old contract expiration and the new contract expiration. Source: Wage file.

Prior real percentage wage change Annual percentage change in the wage over the prior contract:

$$
100\left[\left(w / w_{0}\right)^{\frac{12}{l}}-1\right]
$$

where $w$ is the real wage at the end of the prior contract, $w_{0}$ is the real wage at the beginning of the prior contract, and $\ell$ is the contract duration in months. Source: Wage file.

\section{Percentage change in employment}

Annual percentage change in the number of workers in the bargaining unit from the prior contract to the current contract: 


$$
100 \frac{12}{\ell} \frac{n-n_{0}}{n_{0}}
$$

where $n$ is the number of workers in the current contract, $n_{0}$ is the number of workers in the prior contract, and $\ell$ is the contract duration in months. Source: Wage file.

Wage is primary issue

Indicates that the wage was a primary issue in the work stoppage. Issue codes 100-201, 203210, 401-404, and 1400-1516. Source: Work Stoppage file.

\section{Lockout}

Indicates the work stoppage was a lockout by the firm. Source: Work Stoppage file.

\section{Rotating strike}

Indicates the work stoppage was a rotating strike. Source: Work Stoppage file.

\section{Provincial unemployment rate}

Unemployment rate of persons 15 years or older, monthly by province. Source: Cansim codes D767289, D767842, D767980, D768118, D768256, D768418, D768602, D768734, D768872, D769010, D769173.

\section{Consumer price index (CPI)}

Canadian consumer price index for all items, $1981=100$, monthly. Source: Cansim code D484000.

\section{Elasticity of wage to CPI}

Proportionate change in the nominal wage over the contract divided by the proportionate change in the Canadian CPI. If the contract has no COLA clause the elasticity is zero. Source: Wage file and Cansim.

\section{Provincial real manufacturing wage}

Average hourly earnings of hourly wage-earners in manufacturing, monthly by province, includes all firms with 20 or more employees. Series terminates March 1983; Industry index of hourly earnings used to extend series. Source: Cansim codes D708311, D708602, D708660, D708710,
D708765, D708963, D709312, D709411, D709513, D709612.

Industry index of hourly earnings

Fixed-weighted industry-aggregate index of average bourly earnings, monthly by province, includes all firms with 20 or more employees.

Series starts March 1983; used to extend Provincial real manufacturing wage series. Source: Cansim codes L95705, L95717, L95718, L95719, L95720, L95721, L95722, L95723, L95724, L95725, L95726.

\section{Federal direct taxes}

Total foderal direct taxes in millions, annually by province. Source: Cansim codes D11237, D42001, D42015, D42029, D42043, D42057, D42071, D42085, D42099, D42113, D44217.

\section{Gross domestic product (GDP)}

Provincial gross domestic product at market prices in millions, annually by province. Source: Cansim codes D31530, D31544, D31558, D31572, D31586, D31600, D31614, D31628, D31642, D31656, D44000.

\section{Ratio of taxes to GDP}

Federal direct taxes divided by GDP, annually by province. Source: Cansim.

\section{Linking the Wrk Stoppage and Wage Files}

Unfortunately, strike durations are not included in the Canadian wage file. To get strike durations, one must link records from the work stoppage file. There is no simply way to perform this link. Below we document our approach in linking the 888 strikes from the wage file to the 15,639 private sector strikes from the work stoppage file.

We began by importing selected fields of each file into Paradox. Each record in the wage file is uniquely identified by the agreement number and the renewal number. Each record in the mork stoppage file is uniquely identified by the current year and the work stoppage number. The fields common to both files are the threedigit SIC, jurisdiction, province, union, and 
company name. For the wage file, the contract expiration, the settlement date, and the number of workers in the bargaining unit were also included. For the work stoppage file, the beginning date of the strike, the ending date of the strike, and the maximum number of workers on strike were also included.

The first step was to identify the obvious matches: those records that match on all the common fields - SIC, jurisdiction, province, union, and company name - and have a settlement date that is within a few days of the strike ending date. This initial step successfully identified 606 matches $(68 \%)$. We then successively relaxed the requirements for a potential match, allowing the union codes to differ say, and then visually checking to see which of the potential matches seemed reasonable. In the end, a likely match was found for all but seven of the $\mathbf{8 8 8}$ strikes in the wage file. These seven contracts were then dropped from our sample.

\section{References}

ASHENFELTER, ORLEY AND GEORGE E. JOHNSON (1969), “Bargaining Theory, Trade Unions, and Industrial Strike Activity," American Economic Review, 59, 35-49.

AULD, D. A. L., L. N. ChrISTOFDES, R. SWIDINSKY, AND D. A. WIITON (1981), "The Effect of Settlement Stage on Negotiated Wage Settlements in Canada," Industrial and Labor Relations Review, 34, 234-244.

CARD, DAVID (1988), "Longitudinal Analysis of Strike Activity," Journal of Labor Economics, 6, 147-176.

CARD, DAVID (1990), "Strikes and Bargaining: A Survey of the Recent Literature," American Economic Review Papers and Proceedings, 80, 410-415.
CARD, DAVID (1990), "Strikes and Wages: A Test of a Signalling Model," Quarterly Journal of Economics, 105, 625-660.

CARd, David and Craig A. Olson (1992), "Bargaining Power, Strike Duration, and Wage Outcomes: An Analysis of Strikes in the 1880s," NBER Working Paper 4075.

CRAMTON, Peter (1984), "Bargaining with Incomplete Information: An InfiniteHorizon Model with Continuous Uncertainty," Review of Economic Studies, 51, 579-593.

Cramton, Peter (1992), "Strategic Delay in Bargaining with Two-Sided Uncertainty," Review of Economic Studies, 59, 205-225.

Cramton, Peter and Joseph Tracy (1992), "Strikes and Holdouts in Wage Bargaining: Theory and Data," American Economic Review, 82, 100-121.

Cramton, Peter and Joseph Tracy (1994a), "The Determinants of U.S. Labor Disputes," Journal of Labor Economics, 12, 180-209.

Cramton, Peter and Joseph Tracy (1994b), "Wage Bargaining with Time-Varying Threats," Journal of Labor Economics, 12, forthcoming.

\section{CURRIE, JANET AND SHEENA MCCONNELL} (1991), "Collective Bargaining in the Public Sector: The Effect of Legal Structure on Dispute Costs and Wages," American Economic Review, 81, 693-718.

FARBER, HENRY S. (1978), “Bargaining Theory, Wage Outcomes, and the Occurrence of Strikes," American Economic Review, 68, 262-284.

Fudengerg, DREW, DaVID K. LeVINE, AND PAUL RUUD (1985), "Strike Activity and Wage Settlements," Working Paper, UCLA. 
Gramm, CynThIA L. (1986), "The

Determinants of Strike Incidence and

Severity: A Micro-Level Study," Industrial

and Labor Relations Review, 39, 361-376.

Gramm, CyNTHIA L. (1991), "Employers"

Decisions to Operate During Strikes:

Consequences and Policy Implications, " in Employee Rights in a Changing Economy:

The Issue of Replacement Wrikers, Willaim Spriggs (ed.), Seminar Series, Washington, DC: Economic Policy Institute.

Gramm, Cynthia L., Wallace E. HENDRICKS, AND LAWRENCE M. KAHN (1989), "Inflation Uncertainty and Strike Activity," Industrial Relations, 1, 114-129.

GUNDERSON, MORLEY, JOHN KERVIN, AND FRANK REID (1986), "Logit Estimates of Strike Incidence from Canadian Contract Data," Journal of Labor Economics, 4, 257-276.

GUNDERSON, MORLEY, JOHN KERVIN, AND FRANK REID (1989), "The Effect of Labour Relations Legislation on Strike Incidence," Canadian Journal of Economics, 22, 779794.

GUNDERSON, MORLEY AND ANGELO MELNNO (1990), "The Effects of Public Policy on Strike Duration," Journal of Labor Economics, 8, 295-316.

Gunderson, Morley and W. Craig RIDDELl (1993), Labour Market Economics, Thind Edition, Toronto: McGraw-Hill Ryerson.

HARRISON, ALAN AND MARK STEWART (1989), "Cyclical Fluctuations in Strike Durations," American Economic Review, 79, 827-841.

HARRISON, ALAN AND MARK STEWART (1989), “Is Strike Behavior Cyclical?" Working Paper, McMaster University.
HART, OLIVER (1989), "Bargaining and Strikes," Quarterly Journal of Economics, 104, 25-44.

HAYES, BETH (1984), "Unions and Strikes with Asymmetric Information," Journal of Labor Economics, 2, 57-83.

KENNAN, JOHN (1980), "Pareto Optimality and the Economics of Strike Duration," Journal of Labor Research, 1, 77-94.

KENNAN, JOHN (1980), "The Effect of Unemployment Insurance Payments on Strike Duration," Unemployment Compensation: Studies and Research, 2 , 467-483.

KENNAN, JOHN (1985), "The Duration of Contract Strikes in US Manufacturing," Journal of Econometrics, 28, 5-28.

KENNAN, JOHN (1986), "The Economics of Strikes," in O. Ashenfelter and R. Layard (eds), Handbook of Labor Economics, Volume 2, Amsterdam: Elsevier Science Publishers.

KENNAN, JOHN AND ROBERT WILSON (1989), "Strategic Bargaining Models and Interpretation of Strike Data," Journal of Applied Econometrics, 4, S87-S130.

KENNAN, JOHN AND ROBERT WILSON (1990), "Can Strategic Bargaining Models Explain Collective Bargaining Data?" American Economic Review Papers and Proceedings, 80, 405-409.

KENNAN, JOHN AND ROBERT WILSON (1990), "Theories of Bargaining Delays," Science, 249, 1124-1128.

KENNAN, JOHN AND ROBERT WILSON (1991), "Screening Models of Bargaining with Private Information: An Empirical Application," Working Paper, University of Iowa. 
KENNAN, JOHN AND ROBERT WILSON (1992), "Repeated Wage Bargaining with Private Information," Working Paper, University of Iowa.

KenNAN, JOHN AND ROBERT WILSON (1993), "Bargaining with Private Information," Journal of Economic Literature, 31, 45104.

LACROIX, ROBERT (1986), “A Microeconometric Analysis of the Effects of Strikes on Wages," Relations Industrielles, 41, 111126.

MCConNell, SheENA (1986), "Cyclical Fluctuations in Strike Activity, "Working Paper, Princeton University.

MCConNell, ShEENA (1989), "Strikes, Wages, and Private Information," American Economic Review, 79, 801-815.

OWUSU-GYAPONG, ANTHONY (1993), "Alternative Estimating Techniques for Panel Data on Strike Activity," Review of Economics and Statistics, 68, 526-531.

REDER, MELVIN AND GEORGe NeUMANN (1980), "Conflict and Contract: The Case of Strikes," Journal of Political Economy, $88,867-886$.

RIDDELL, W. CRAIG (1980), “The Effects of Strikes and Strike Length on Negotiated Wage Settlements," Working Paper, University of British Columbia.

TRACY, JOSEPH S. (1986), “An Investigation into the Determinants of U. S. Strike Activity," American Economic Review, 76, 423-436.

TRACY, JoSEPH S. (1987), "An Empirical Test of an Asymmetric Information Model of Strikes," Journal of Labor Economics, 5, 149-173.
VROMAN, SUSAN, B. (1989), “A Longitudinal Analysis of Strike Activity in U. S. Manufacturing: 1957-1984," American Economic Review, 79, 816-826.

VRoman, WaYNe (1984), "Wage Contract Settlements in US Manufacturing," Review of Economics and Statistics, 661-665.

ANTI-INFLATION BOARD (1979), Chronicles of the Anti-Inflation Board, Ottawa: AntiInflation Board.

CCH CANADIAN LTD. (1993), Canadian Labour Law Reponter, North York, Ontario: CCH Canadian Lud.

Labour CANADA, Major Wage Settlements (electronic data base), Ottawa: Labour Canada.

LABOUR CANADA, Work Stoppages (electronic data base), Ottawa: Labour Canada.

LABOUR CANADA (various issues), Federal and Provincial Industrial Relations Dispute Settlement Procedures, Ottrwa: Legislative Research Branch.

LABOUR CANADA (various issues), Industrial Relations Legislation in Canada, Ottawa: Labour Canada.

LABOUR CANADA (various issues), Legislative Review, Ottawa: Legislative Research Branch.

Statistics Canada, Cansim (electronic data base), Ottawa: Statistics Canada. 